\title{
Connecticut Transit (CTTRANSIT) Fuel Cell Transit Bus: Second Evaluation Report
}

\section{Technical Report} NREL/TP-560-45670-1

Revised September 2009

Kevin Chandler, Battelle Leslie Eudy, National Renewable Energy Laboratory

Link to Appendices

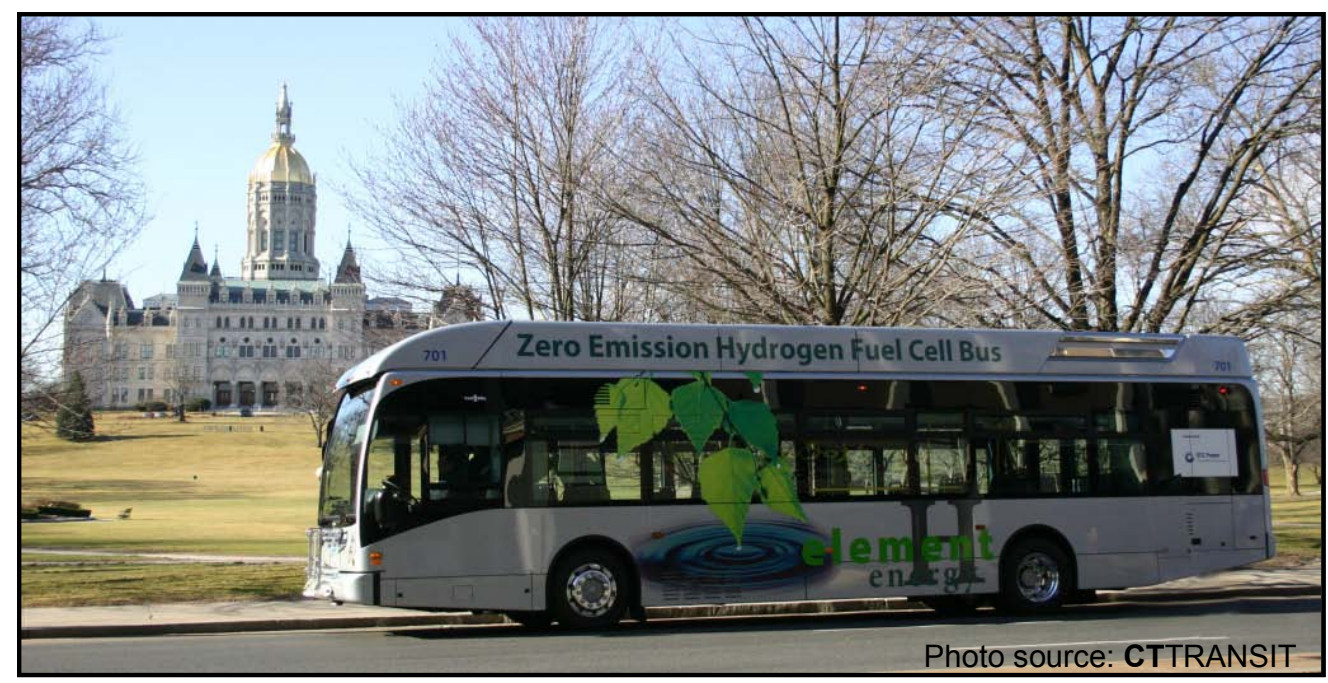

Photo source: CTTRANSIT

NREL is operated for DOE by the Alliance for Sustainable Energy, LLC Contract No. DE-AC36-08-G028308
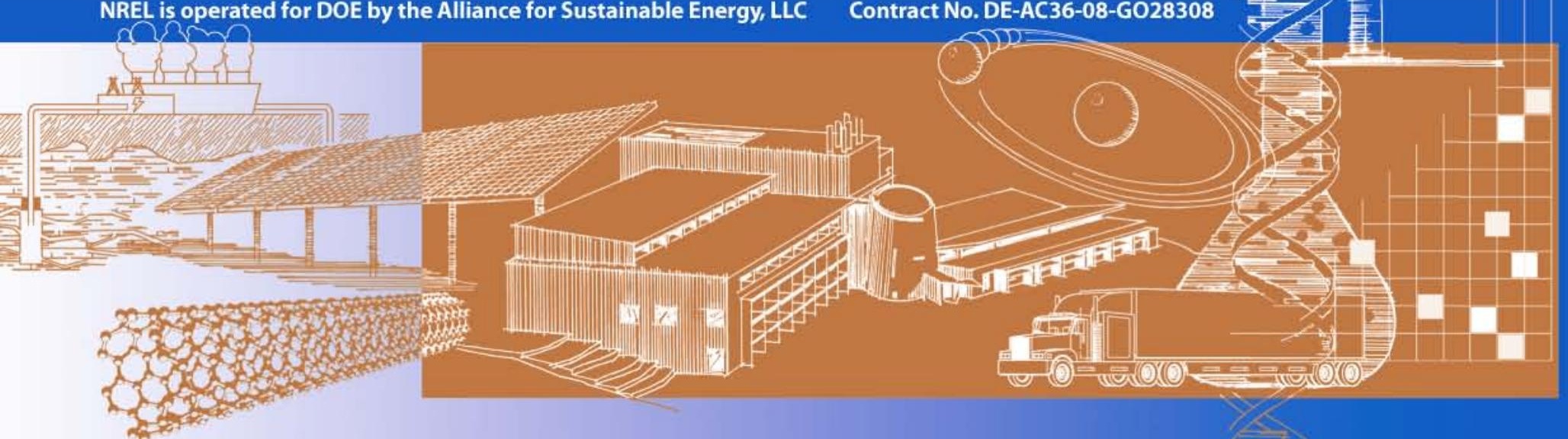


\section{Connecticut Transit (CTTRANSIT) Fuel Cell Transit Bus: Second Evaluation Report}

Technical Report NREL/TP-560-45670-1

Revised September 2009

Kevin Chandler, Battelle Leslie Eudy, National Renewable Energy Laboratory

Prepared under Task No. FC08.7820

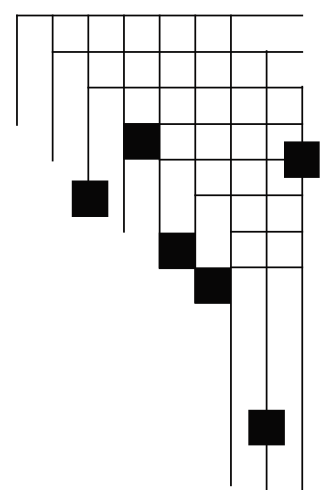




\section{NOTICE}

This report was prepared as an account of work sponsored by an agency of the United States government. Neither the United States government nor any agency thereof, nor any of their employees, makes any warranty, express or implied, or assumes any legal liability or responsibility for the accuracy, completeness, or usefulness of any information, apparatus, product, or process disclosed, or represents that its use would not infringe privately owned rights. Reference herein to any specific commercial product, process, or service by trade name, trademark, manufacturer, or otherwise does not necessarily constitute or imply its endorsement, recommendation, or favoring by the United States government or any agency thereof. The views and opinions of authors expressed herein do not necessarily state or reflect those of the United States government or any agency thereof.

Available electronically at http://www.osti.gov/bridge

Available for a processing fee to U.S. Department of Energy and its contractors, in paper, from:

U.S. Department of Energy

Office of Scientific and Technical Information

P.O. Box 62

Oak Ridge, TN 37831-0062

phone: 865.576 .8401

fax: 865.576 .5728

email: mailto:reports@adonis.osti.gov

Available for sale to the public, in paper, from:

U.S. Department of Commerce

National Technical Information Service

5285 Port Royal Road

Springfield, VA 22161

phone: 800.553.6847

fax: 703.605.6900

email: orders@ntis.fedworld.gov

online ordering: http://www.ntis.gov/ordering.htm 


\section{ERRATA SHEET}

NREL REPORT/PROJECT NUMBER: NREL/TP-560-45670-1

TITLE: Connecticut Transit (CTTRANSIT) Fuel Cell Transit Bus: Second Evaluation Report AUTHOR(S): Kevin Chandler and Leslie Eudy

ORIGINAL PUBLICATION DATE: 6/2009

DATE OF CORRECTIONS (MM/YYYY): 9/2009

The following corrections were made to this report/document:

Revised September 2009:

- Page 12, figure 10 added 


\title{
Acknowledgements
}

This evaluation at Connecticut Transit (CTTRANSIT) would not have been possible without the support and cooperation of many people. The authors thank the following.

\author{
U.S. Department of Energy \\ John Garbak
}

U.S. Department of Transportation, Federal Transit Administration

Walter Kulyk

Christina Gikakis

National Renewable Energy Laboratory

Keith Wipke

Terry Penney

\section{CTTRANSIT}

Stephen Warren

Mitch Howard

Russ Osborn

Nathan Shultz

James Dowd

Thai Ly

\section{UTC Power}

David Boudreau

Matthew Riley

Jennifer Stewart

Rakesh Radhakrishnan

\section{ISE Corporation}

Paul Scott

Kevin Stone

Gary Wilms

MES-DEA S.A.

Renato Manzoni

Michael Metzger 


\section{Acronyms and Abbreviations}

$\mathrm{AC}$

ConnDOT

CSA

DGE

DOE

DOT

DPF

$\mathrm{ft}$.

FTA

gal.

HFCIT

hp

HVAC

in.

$\mathrm{kg}$

$\mathrm{kW}$

$\mathrm{kWh}$

lb.

MBRC

mpg

mph

NFCBP

NREL

PEM

PMI

psi

$\mathrm{RC}$

$\mathrm{rpm}$

SOC alternating current

Connecticut Department of Transportation

cell stack assembly

diesel gallon equivalent

U.S. Department of Energy

U.S. Department of Transportation

diesel particulate filter

feet

Federal Transit Administration

gallon

Hydrogen, Fuel Cells, and Infrastructure Technology horsepower

heating, ventilation, and air conditioning

inches

kilogram

kilowatts

kilowatt hour

pounds

miles between roadcalls

miles per gallon

miles per hour

National Fuel Cell Bus Program

National Renewable Energy Laboratory

proton exchange membrane

preventive maintenance inspection

pounds per square inch

roadcall

revolutions per minute

state of charge 


\section{Executive Summary}

This report describes operations at Connecticut Transit (CTTRANSIT) in Hartford for one prototype fuel cell bus and three new diesel buses operating from the same location. The evaluation period in this report (January 2008 through February 2009) has been chosen to coincide with a UTC Power propulsion system changeout that occurred on January 15, 2008. After this changeout of the propulsion system, the operation of the fuel cell bus was increased as much as the technology would allow. UTC Power reported that this change of the power system incorporated many of the lessons learned from operation including previous early power-loss issues. This evaluation report is focused on measuring the accomplishments and lessons learned from this fuel cell power system and the next steps.

In this report, the fuel cell bus is considered to be prototype technology that is in the process of being commercialized. The analysis and comparison discussions regarding standard diesel buses help baseline the progress of the fuel cell bus technology. There is no intent to consider this implementation of fuel cell buses as commercial (or full-revenue transit service). This evaluation focuses on documenting progress and opportunities for improving the vehicles, infrastructure, and procedures.

\section{Public Awareness}

CTTRANSIT continues to report a high level of interest in the fuel cell bus demonstration from the local community and the region. In the fall of 2008, CTTRANSIT conducted two surveys to determine the level of awareness and acceptance for fuel cell bus technology in the Hartford area. The agency developed two lists of questions: one targeted to passengers and the other for the bus operators. Details of these survey results are provided in the Public Awareness section.

\section{Evaluation Results}

Table ES-1 provides a summary of results for several categories of data presented in this report. During the evaluation period, the fuel cell bus accumulated 12,115 miles, and the fuel cell systems accumulated 2,049 hours. These numbers indicate an overall average operating speed of $5.9 \mathrm{mph}$, which is significantly less than the average service at CTTRANSIT (12 mph) and the Star route $(10 \mathrm{mph})$. Note that the maintenance costs are high for the fuel cell bus because of the amount of participation by the CTTRANSIT mechanics in fuel cell and hybrid propulsion maintenance. These costs were not charged back to the manufacturers as warranty. 
Table ES-1. Summary of Evaluation Results

\begin{tabular}{|l|c|c|}
\hline \multicolumn{1}{|c|}{ Data Item } & Fuel Cell & Diesel \\
\hline Number of Buses & 1 & 3 \\
\hline Data Period & $1 / 08-2 / 09$ & $1 / 08-2 / 09$ \\
\hline Number of Months & 14 & 14 \\
\hline Total Mileage in Period & 24,127 & 137,127 \\
\hline Total Fuel Cell Hours & 3,544 & $\mathrm{~N} / \mathrm{A}$ \\
\hline Average Monthly Mileage per Bus & 1,723 & 3,265 \\
\hline Average Operating Speed (mph) & 6.8 & 12 \\
\hline Availability (Target is 85\%) & $77 \%$ & $\mathrm{~N} / \mathrm{A}^{\mathrm{a}}$ \\
\hline Fuel Economy (Miles/kg) & 4.73 & $\mathrm{~N} / \mathrm{A}$ \\
\hline Fuel Economy (Miles/DGE ${ }^{\mathrm{b}}$ ) & 5.34 & 3.66 \\
\hline Miles Between Roadcalls-All & 1,149 & 7,618 \\
\hline Miles Between Roadcalls-Propulsion Only & $1,270^{\mathrm{c}}$ & 8,570 \\
\hline Total Maintenance, \$/Mile & 1.04 & 0.42 \\
\hline Maintenance-Propulsion Only, \$/Mile & 0.76 & 0.12 \\
\hline
\end{tabular}

a. Availability for diesel buses is not collected - data was not available.

b. Diesel gallon equivalent.

c. For fuel cell propulsion only, Miles Between Roadcalls (MBRC) was 6,032.

d. Work-order maintenance cost.

\section{What's Next for CTTRANSIT?}

CTTRANSIT started operation with their fuel cell bus in April 2007 and continues to operate the bus. The fuel cell power system was again replaced on November 24, 2008, with UTC Power's newest version of its fuel cell power system. At that point, the fuel cell bus had not yet reached the full warranty period, with 400 hours of operation remaining on the fuel cell power system. CTTRANSIT and UTC Power agreed that the newer fuel cell power system would have a warranty period that included the remaining 400 hours so that the current system has a warranty period of 4,400 hours of operation. This additional warranty $(4,000 \mathrm{hrs})$ is being included in anticipation of a contract for continued operation of this bus under federal funding. As the demonstration of this single fuel cell bus continues, CTTRANSIT plans to reduce operation to weekday service and some Saturday service. This change is being done to reduce operating costs and is expected to extend the life of this demonstration bus another two to two and a half years.

The change in approach to service of this fuel cell bus does not indicate a loss of interest in the project but a redirect toward the new fuel cell buses planned for CTTRANSIT in Hartford. The current plan is for CTTRANSIT to receive up to four new fuel cell buses from Van Hool and UTC Power as part of FTA's National Fuel Cell Bus Program through the Northeast Advanced Vehicle Consortium and UTC Power, along with a fifth bus being purchased by CTTRANSIT under a state grant. The first of the new buses for CTTRANSIT is expected to arrive between September and October 2009. 


\section{Table of Contents}

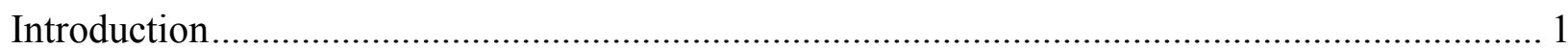

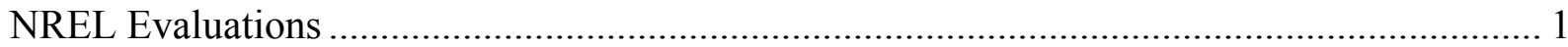

Fuel Cell Bus Evaluation at CTTRANSIT …………........................................................ 1

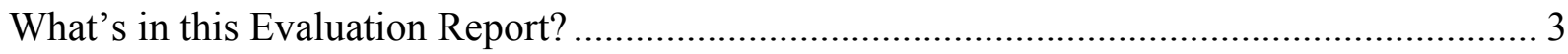

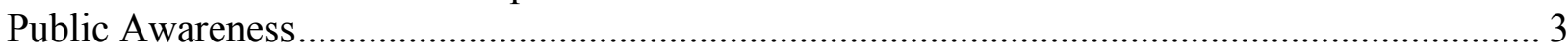

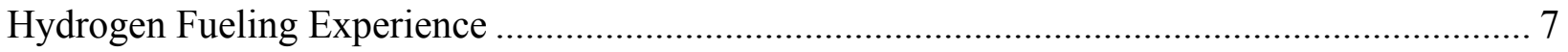

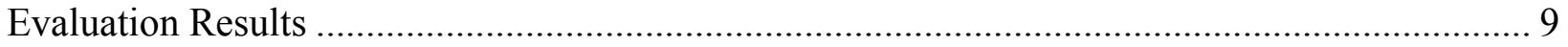

Fuel Cell Bus Operation........................................................................................... 9

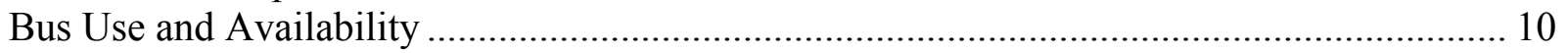

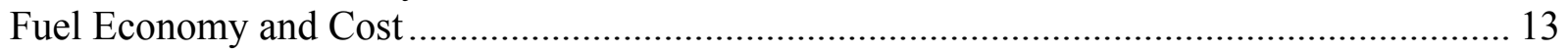

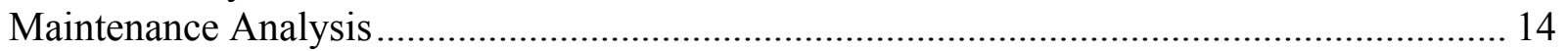

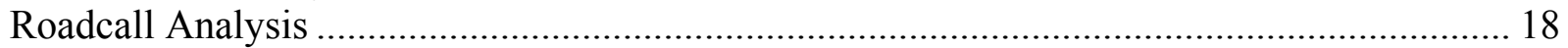

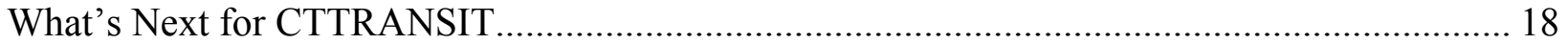

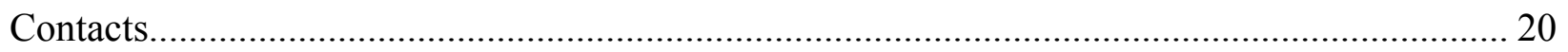

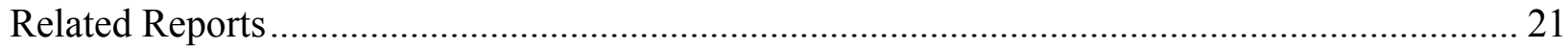




\section{Introduction}

Connecticut Transit (CTTRANSIT) ${ }^{1}$ has been operating one fuel cell bus in revenue service in Hartford, Connecticut, since April 2007. The early operation of this bus has been documented in a previous report from the U.S. Department of Energy (DOE) and the National Renewable Energy Laboratory (NREL) ${ }^{2}$. This report continues the evaluation of the fuel cell bus and three diesel buses as a baseline.

\section{NREL Evaluations}

NREL has been evaluating alternative fuel and advanced propulsion transit buses for DOE and the Federal Transit Administration (FTA) since the early 1990s. NREL's first evaluation of hydrogen fuel cell transit buses for DOE was in 2000 and continues with this evaluation at CTTRANSIT. These evaluations are focused on determining the status of hydrogen and fuel cell systems and corresponding infrastructure in transit applications to assess the progress toward technology readiness. NREL uses a standard data-collection and analysis protocol originally developed for DOE heavy-duty vehicle evaluations, and a joint evaluation plan has been documented for transit bus evaluations ${ }^{3}$. Appendix A describes NREL's transit bus evaluation activities for DOE and FTA.

\section{Fuel Cell Bus Evaluation at CTTRANSIT}

CTTRANSIT provides fixed-route transportation services to three major metropolitan areas in the state: Hartford, New Haven, and Stamford. The Hartford Division is the largest of the three areas, operating a total of 237 buses over 30 local routes and 12 express routes in and around the capital area. CTTRANSIT has been investigating new technologies and fuels for its fleet that are more efficient and produce fewer emissions. Appendix B provides more information on CTTRANSIT.

In April 2007, CTTRANSIT began demonstrating one prototype fuel cell bus manufactured by Van Hool and ISE Corp. The prototype fuel cell bus features an electric hybrid drive system with a UTC Power PureMotion ${ }^{4} 120$ Fuel Cell Power System and ZEBRA batteries for energy storage. This fuel cell bus was purchased by UTC Power from the Alameda-Contra Costa Transit District (AC Transit) fuel cell bus order, and then the bus was sold to CTTRANSIT. AC Transit operates three fuel cell buses identical to the one at CTTRANSIT. There is only one other identical fuel cell bus operating in the U.S., and it operates at SunLine Transit Agency. NREL has been evaluating all three locations operating these Van Hool/ISE Corp./UTC Power fuel cell buses. The CTTRANSIT fuel cell bus is shown in Figure 1.

\footnotetext{
${ }^{1}$ CTTRANSIT Web site: www.cttransit.com.

${ }^{2}$ CTTRANSIT, Fuel Cell Transit Bus: Preliminary Evaluation Results, October 2008, NREL/TP-560-43847, www.nrel.gov/hydrogen/pdfs/43847.pdf.

${ }^{3}$ Hydrogen and Fuel Cell Transit Bus Evaluations: Joint Evaluation Plan for the U.S. Department of Energy and the Federal Transit Administration, NREL/MP-560-42781, May 2008, www.nrel.gov/hydrogen/pdfs/42781-1.pdf.

${ }^{4}$ PureMotion is a trademark of UTC Power.
} 


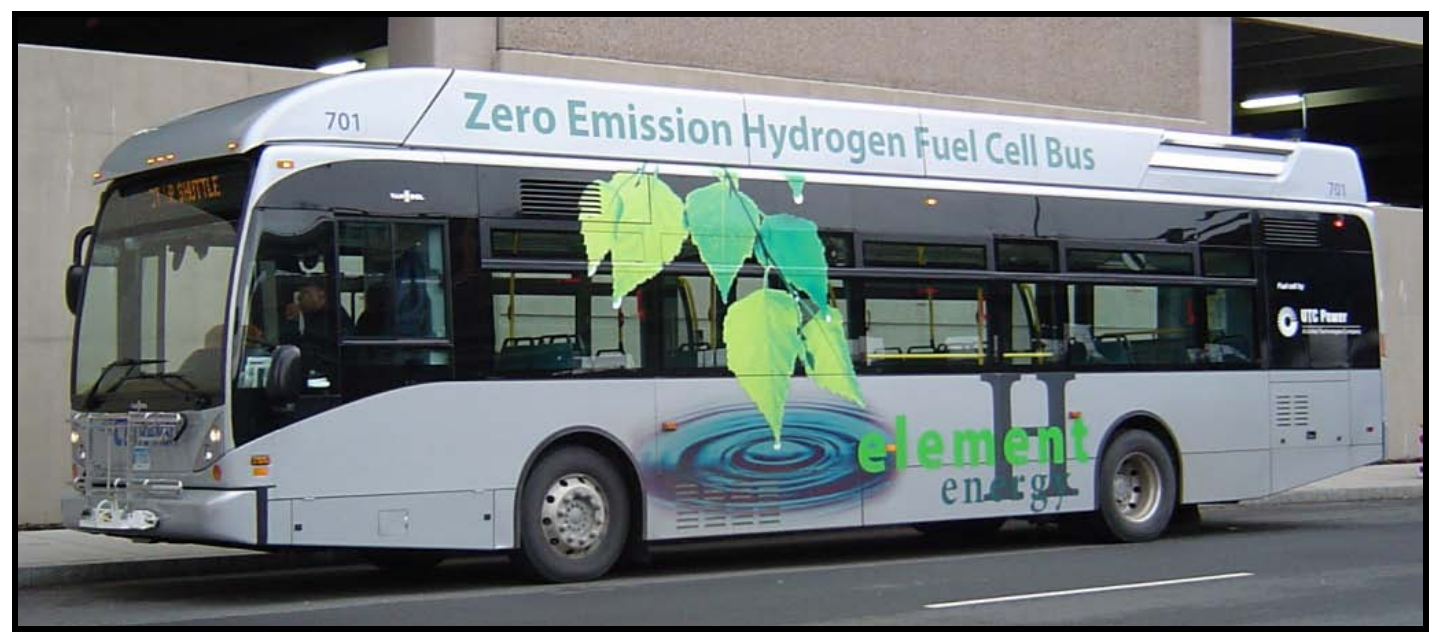

Figure 1. CTTRANSIT fuel cell bus

Three diesel buses operating from the same location as the fuel cell bus have been selected to use as a baseline comparison. These diesel baseline buses are $40-\mathrm{ft}$. New Flyer buses with Cummins ISL engines as shown in Figure 2. These diesel buses use some of the first model year 2007 diesel ISL engines from Cummins, and they have an actively regenerated diesel particulate filter (DPF). Appendix $\mathrm{C}$ provides more detail about the bus technologies included in this evaluation.

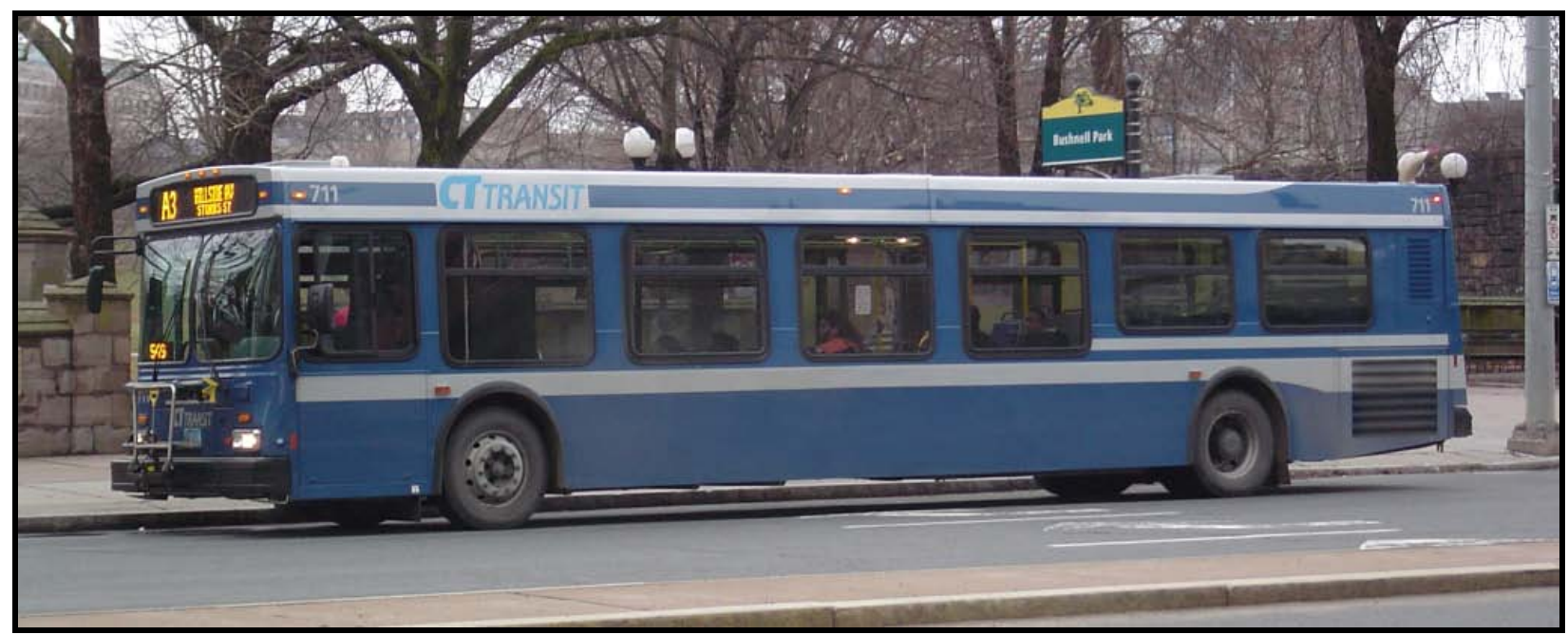

Figure 2. One of CTTRANSIT's diesel buses (same as those used in evaluation)

CTTRANSIT currently has access to hydrogen at the UTC Power headquarters, about seven miles away. The UTC Power fueling station features liquid hydrogen storage and compression. The fuel is vaporized and dispensed into the bus as gaseous hydrogen. The hydrogen, supplied by Praxair from their location near Niagara Falls, is produced renewably as a by-product of a chemical process. CTTRANSIT modified its existing facility to allow for safe storage and minor maintenance of the hydrogen-fueled bus. Appendix D provides more detail about modifications to CTTRANSIT's maintenance and bus storage facilities.

The CTTRANSIT fuel cell bus has been operating in standard service almost exclusively on their Star Shuttle route, which is a downtown loop that operates every 12 minutes. This route is 
5.5 miles long and has an average speed of $10 \mathrm{mph}$. The fuel cell bus is also used for events in Hartford, other locations in the state, and occasionally has been transported out of state for events. During the evaluation period in this report, the fuel cell bus operated on several other routes on the weekends. This additional operation on other routes has been minor due to the low maximum speed of the fuel cell bus at $48 \mathrm{mph}$.

The diesel buses have continued to operate in normal operation in Hartford (randomly dispatched). The average speed of diesel bus operation at Hartford is $12 \mathrm{mph}$. This average speed for the diesel buses has been significantly higher than the average speed experienced by the fuel cell bus even though the Star Shuttle route is scheduled at an average speed of $10 \mathrm{mph}$. During the evaluation period, the fuel cell bus experienced an average speed of $6.8 \mathrm{mph}$. The primary reason for this lower average speed is that the fuel cell is not shut down when the bus is idle between runs. There are no emission issues as there are with diesel buses, and there is a desire to avoid shutting down the fuel cell system while the bus is out on the route.

\section{What's in this Evaluation Report?}

The previous NREL evaluation report included implementation and early operational experience with the fuel cell bus including data from the start of fuel cell bus operation in April 2007 through June 2008. This evaluation update report describes results and experiences with the fuel cell and diesel buses from January 2008 through February 2009. This new data period has some overlap with the previous evaluation report.

The evaluation period in this coincides with a UTC Power propulsion system changeout that occurred on January 15, 2008. With this changeout of the propulsion system, the operation of the fuel cell bus was increased as much as the technology would allow. The fuel cell bus started operating two eight-hour shifts on the Star Shuttle route during the weekdays and started operating on the weekends as well (including routes beyond the Star Shuttle route as mentioned above). UTC Power reported that this change of the power system incorporated many of the lessons learned from previous operation, including premature power-loss issues reported previously. This evaluation report is focused on measuring the accomplishments and lessons learned from this fuel cell power system and the next steps.

\section{Public Awareness}

CTTRANSIT continues to report a high level of interest in the fuel cell bus demonstration from the local community and the region. The agency receives requests to demonstrate the bus at various events and accommodates as many as possible. During the evaluation period for this report, the agency participated in 22 events to showcase the fuel cell bus, including hydrogen fueling demonstrations at the UTC Power hydrogen fueling station, shuttle service for conventions in downtown Hartford, and demonstrations at neighboring transit agencies and conferences.

In the fall of 2008, CTTRANSIT conducted two surveys to determine the level of awareness and acceptance for fuel cell bus technology in the Hartford area. The agency developed two lists of questions: one targeted to passengers and the other for the bus operators. Some of the results are presented in this section. Appendix E provides a summary of all the results. 
The first survey, conducted in August 2008, was given to passengers on the fuel cell bus as it was operated on the A-Asylum Ave/Hillside route. A total of 79 passengers completed the survey, which is an estimated $80 \%$ of the riders during that shift. The CTTRANSIT marketing department administered the survey, which consisted of 16 questions designed to gather passengers' awareness and opinions of the technology. Most of the respondents $(82 \%)$ were first-time riders of the fuel cell bus. This result is likely because the bus was being operated on a route other than the downtown shuttle, which is the primary route for the bus. More than half the respondents $(66 \%)$ were aware they had boarded a special hydrogen bus. Although the respondents were not well aware of specific aspects of fuel cell buses, their opinions about the technology were positive.

The passengers were asked if they were aware of several aspects of the fuel cell bus. Figure 3 provides the responses. More than $60 \%$ of the respondents did not know that the fuel cell bus has no emissions, that it converts braking energy to charge the batteries, or that the majority of fuel cell buses in the United States today operate in California. When asked about the fuel cell bus performance with respect to noise, acceleration, braking, and vibration compared with a standard diesel bus, the respondents rated the fuel cell bus better. Figure 4 shows the passengers' opinions on the fuel cell bus performance. When asked about the noise level of the fuel cell bus, $90 \%$ of the passengers felt it was better compared with a standard diesel bus. The passengers also responded favorably about the vibration of the fuel cell bus; $89 \%$ felt it vibrated less than a standard bus. When questioned about braking and acceleration, $82 \%$ of the respondents felt the fuel cell bus had better braking and acceleration than a standard bus.

When asked about the most pleasing feature of the fuel cell bus, $45 \%$ of the responses were related to the interior comfort of the bus. Riders felt the bus was more spacious, the seats were comfortable, and the air conditioning worked well. Other riders commented on the appearance $(18 \%)$, the environmental aspects $(12 \%)$, and the smooth ride $(11 \%)$ of the fuel cell bus. The passengers were also questioned about the most annoying feature of the bus. The majority of respondents $(43 \%)$ reported that nothing was annoying on the bus while others $(42 \%)$ reported issues with various bus-related features, such as the seating layout, the farebox height, and the location of the stop-request buttons. When asked if they would prefer to ride in a hydrogen fuel cell bus or a standard diesel bus, $84 \%$ of the passengers preferred the fuel cell bus. The reasons provided for this preference were related to the comfort of the bus $(35 \%)$ and the environmental aspects $(31 \%)$. The majority of respondents $(81 \%)$ also felt that riding on the fuel cell bus had improved their opinion of the technology. 


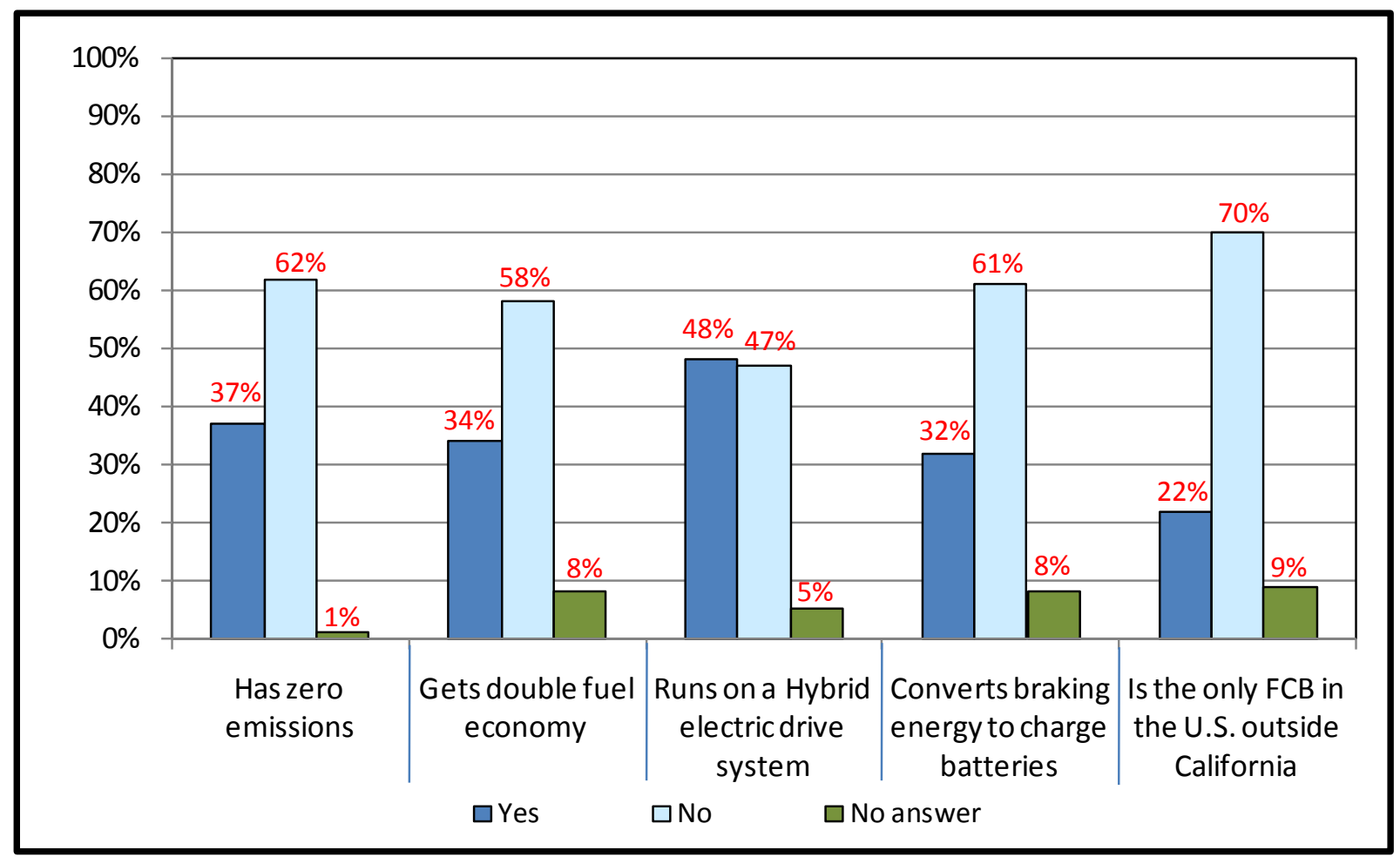

Figure 3. Passenger awareness of various aspects of the fuel cell bus

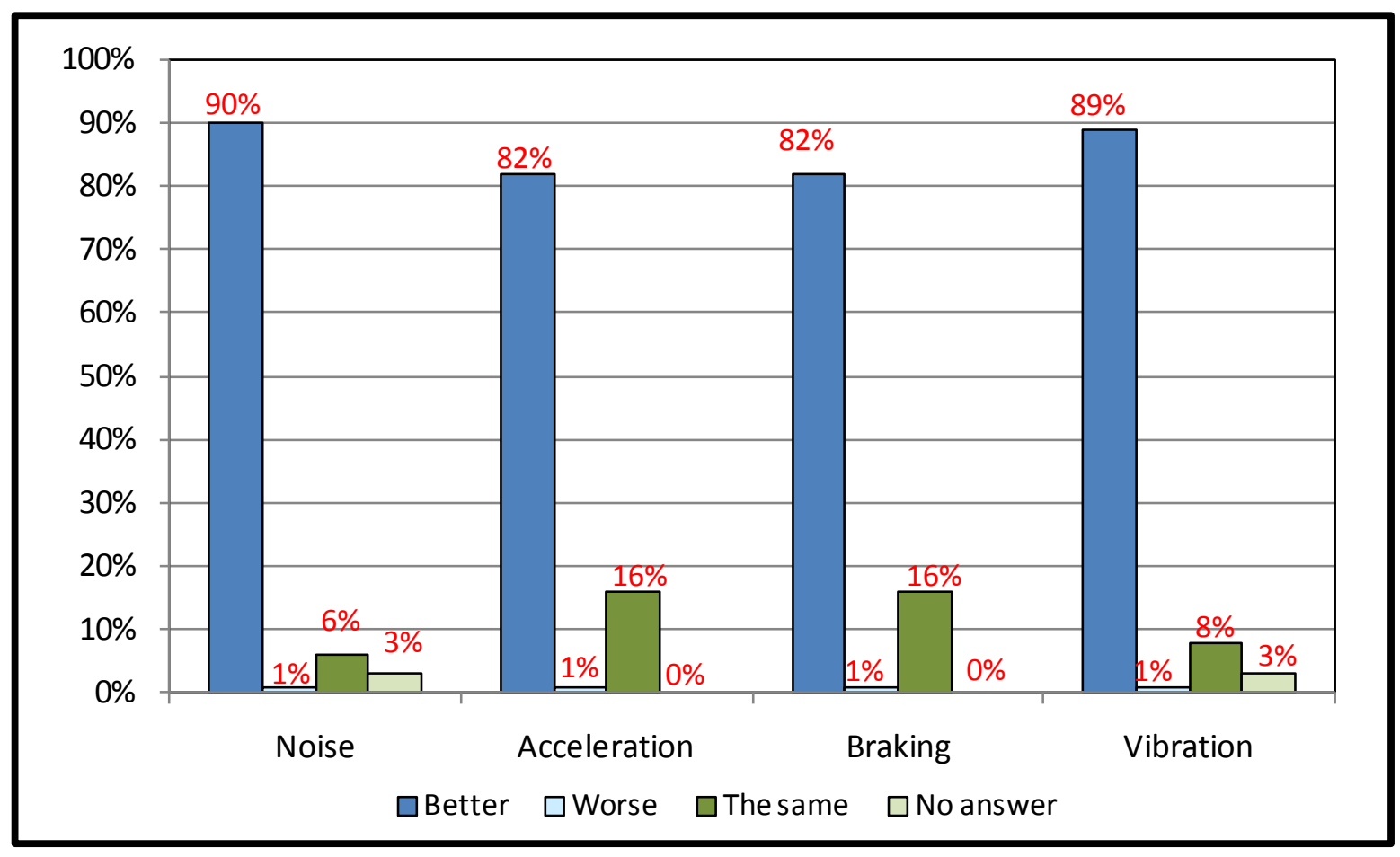

Figure 4. Passenger response to fuel cell bus performance compared with a standard diesel bus 
The second survey conducted by CTTTRANSIT was given to a group of bus operators. The survey consisted of 16 questions, including several that were included in the passenger survey. Of the 21 operators completing the survey, $43 \%$ had driven the fuel cell bus on the Star Shuttle route, and $38 \%$ had driven the bus on other routes. Nearly half the operators $(48 \%)$ reported having driven the fuel cell bus occasionally, and $29 \%$ had driven it often. When asked if it was hard to get used to driving the fuel cell bus, $62 \%$ felt it was not hard to get used to, and only $38 \%$ felt it was a little hard. None of the drivers surveyed felt it was hard to get used to driving the fuel cell bus.

When asked about the performance of the fuel cell bus compared with a standard diesel bus, the operator responses were quite different from the passengers' responses. Figure 5 shows the operators' opinions of the fuel cell bus performance. The majority of operators $(95 \%)$ agreed that the fuel cell bus was quieter than a diesel bus. Most operators (71\%) also felt that the fuel cell bus had less vibration than that of a diesel bus. Only $43 \%$ of the operators felt the acceleration was better while 33\% felt it was worse than a standard diesel bus. More than half the operators felt the braking on the fuel cell bus was the same as that of a diesel bus.

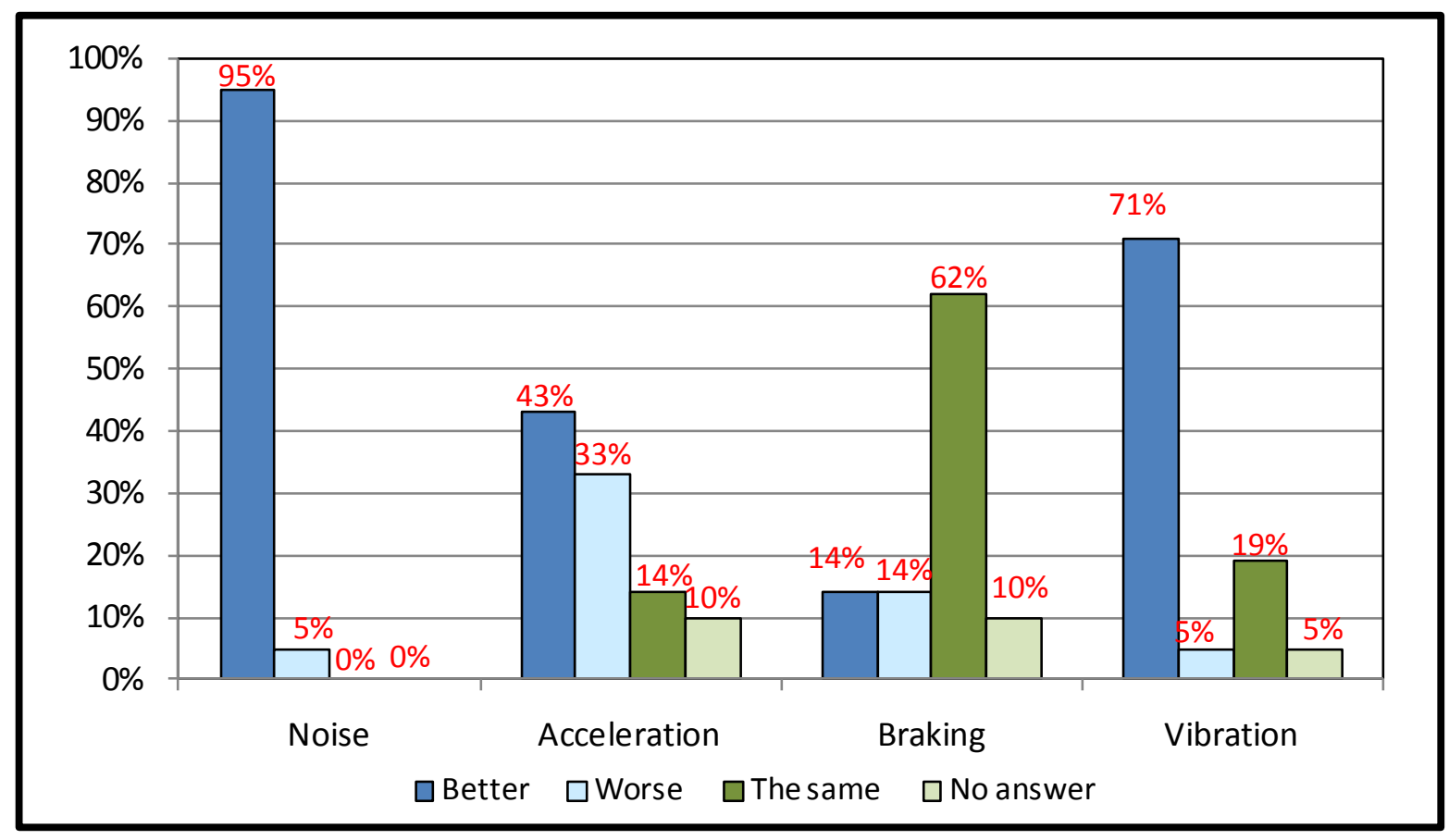

Figure 5. Operators' responses on performance of the fuel cell bus compared with a standard diesel bus

The operators were also asked their opinions on the most pleasing and most annoying feature of the fuel cell bus. The most common response for a pleasing feature (35\%) was that the bus provided a quiet ride. Other operators noted the positive environmental benefits of the fuel cell bus. For the most annoying feature, half the operators responded that they had experienced issues with the bus braking system. 


\section{Hydrogen Fueling Experience}

When the fuel cell bus needs hydrogen, a CTTRANSIT staff member drives it to the UTC Power facility, which is about seven miles northeast of the bus depot. The station is located behind locked gates in a secure area of the UTC Power property. The bus driver calls ahead to ensure that trained staff are available to provide access to this secure area and to operate the station. At this point in the demonstration, only trained UTC Power employees fuel the bus.

Early in the project, the process for fueling the bus took approximately one hour. This time was due mainly to procedures developed for safety, which included placing traffic cones to block other vehicle access, hook up, and fuel dispensing, and sometimes also was due to station startup time. The time needed to drive the bus to and from the site required significant resources from the transit agency. As the project partners have become more comfortable with the fueling process, UTC Power has worked to streamline the procedures and reduce the overall time.

Fueling times are now approximately 30 minutes.

Figure 6 shows the monthly total hydrogen use by CTTRANSIT's fuel cell bus. The fuel usage starts low and is then generally higher from June through December 2008 during increased operation of the fuel cell bus. At the beginning of the data period, there were low months of fuel usage mostly due to traction battery and electric motor issues. Fuel usage was also lower at the end of the data period due to problems with a pressure relief device in the hydrogen system on the bus. The station availability during this timeframe was $100 \%$.

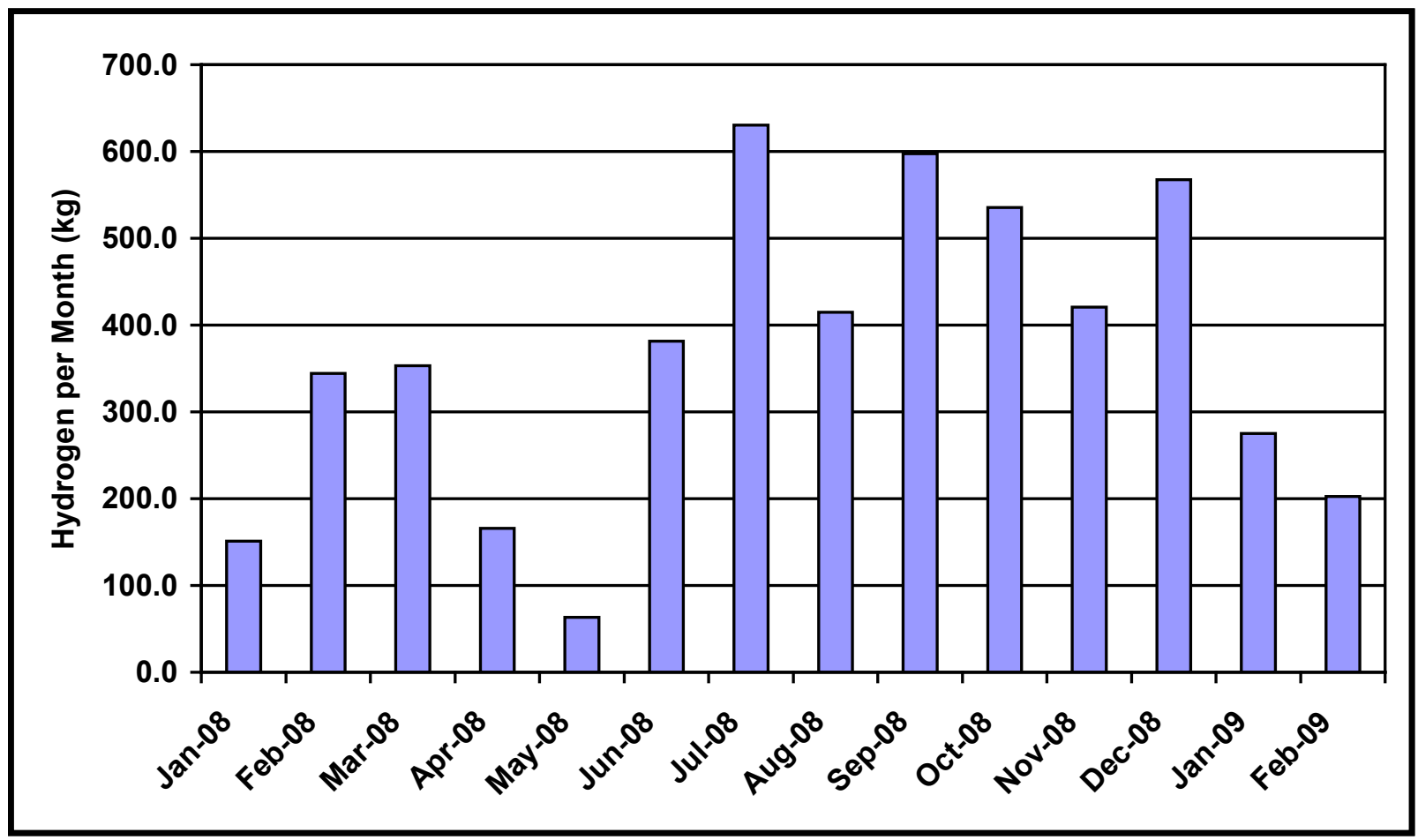

Figure 6. Monthly total hydrogen use by CTTRANSIT's fuel cell bus

Figure 7 shows the distribution of hydrogen amounts per fill. The fuel cell bus was filled 219 times with a total of $5,103 \mathrm{~kg}$ of hydrogen during the evaluation period and an average fill 
amount of $23.3 \mathrm{~kg}$. Figure 8 shows the number of fueling events and average time per fill per month. The average fueling time was 32 minutes during the evaluation period. Note that the fueling time includes the time required to set up safety measures around the fueling station to keep other vehicles out of the area.

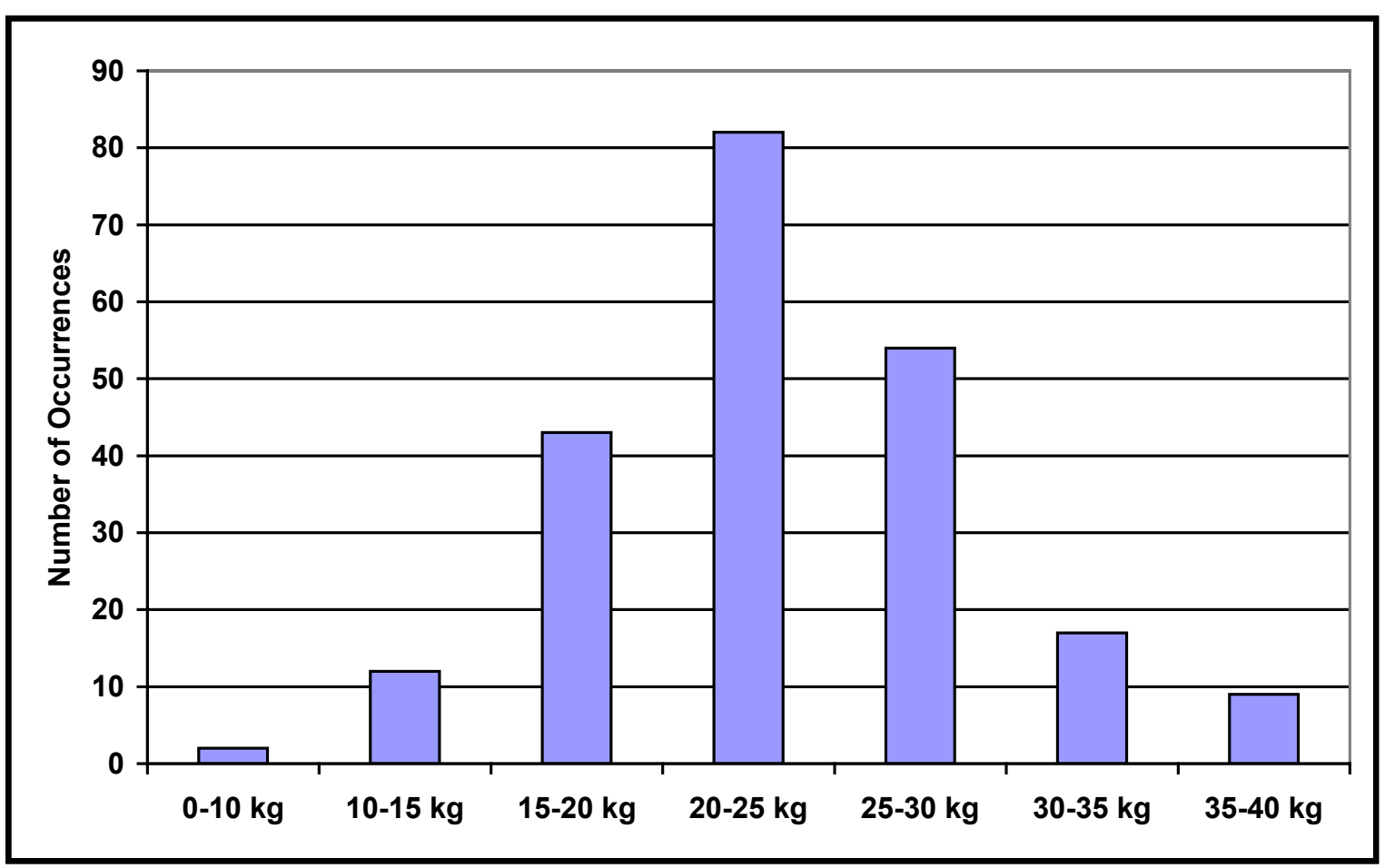

Figure 7. Distribution of average fill amounts for the fuel cell bus

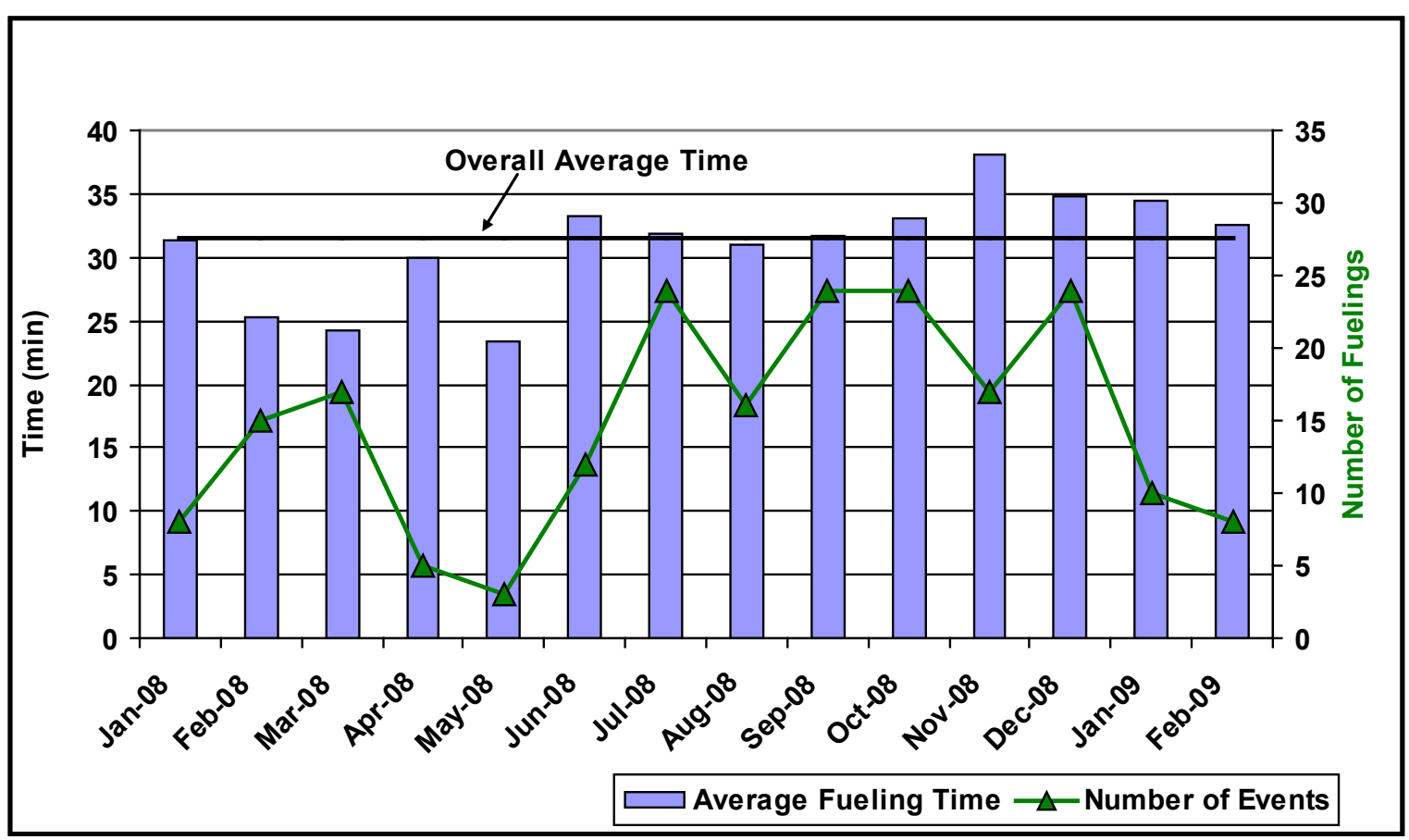

Figure 8. Average time per fueling and number of fueling events per month 


\section{Evaluation Results}

The evaluation period presented in this report includes operation of the fuel cell and diesel baseline buses from January 2008 through February 2009 (14 months). In this evaluation, the fuel cell bus is considered prototype technology in the process of being commercialized. The analysis and comparisons with standard diesel buses help create a baseline for measuring the progress of the fuel cell bus technology. There is no intent to consider this implementation of fuel cell buses as commercial (or full-revenue transit service). This evaluation focuses on documenting progress and opportunities for improving the vehicles, infrastructure, and procedures. A full summary of the evaluation results is provided in Appendix F, and a summary of results in SI units is provided in Appendix G.

\section{Fuel Cell Bus Operation}

As previously mentioned, the fuel cell power system was replaced on January 15, 2008. The manufacturer of the fuel cell power system (UTC Power) expected this newer version to resolve many previous issues that led to the fuel cell power system degrading in power and needing to be replaced. When this new power system was installed, the intent was that the fuel cell bus at CTTRANSIT would be used as much as the technology would allow in an attempt to prove operation of the power system up to 4,000 hours.

Maximum service for the fuel cell bus was designed to be two eight-hour shifts of operation on the Star Shuttle route for seven days per week along with some operation of the fuel cell bus on other routes during the weekends. However, the operation on other routes was limited to only a few because the maximum speed of the fuel cell bus is $48 \mathrm{mph}$ (as reported previously). The bus manufacturer (Van Hool) purposefully chose a rear axle setting that holds the maximum speed to $48 \mathrm{mph}$ because of concerns with the height of the bus, center of gravity, and the possibility of rollover at higher speeds. By the end of the evaluation period in this report, CTTRANSIT and UTC Power agreed that this fuel cell bus would generally operate only on the Star Shuttle route, discontinuing any attempt to operate the bus on other routes during the weekends.

One major constraint with the longer operation time of the fuel cell bus is the need to charge the traction batteries overnight before the next morning's pullout. A full charge for the traction batteries requires between 4 and 4.5 hours. During bus operation on the route, the batteries are kept at $50 \%$ to $60 \%$ state of charge (SOC) to allow for significant energy regeneration from braking back into the batteries. Another major constraint for the increased use of the fuel cell bus was the proper operation of the traction batteries. As reported previously, the use of three ZEBRA batteries in the fuel cell bus has presented problems with failures of the traction batteries themselves along with a problem of the hybrid propulsion system sensing an over-voltage situation and shutting the system down because of issues between the hybrid propulsion system control software and the traction battery control software. These situations are generally unresolved and have caused significant downtime for the fuel cell bus as discussed in the next section.

The CTTRANSIT fuel cell bus along with one of the AC Transit fuel cell buses (FC3) have served as an accelerated testing group for the UTC Power fuel cell system. Both buses have been operating the newer fuel cell system as much as the technology would allow until almost the end of calendar year 2008. The CTTRANSIT fuel cell bus had the fuel cell power system 
replaced on November 24, 2008, and the AC Transit fuel cell bus had the fuel cell power system replaced in December 2008. These replacements were done to allow these two buses to receive UTC Power's next version of its power system for testing prior to being released for a new order of Van Hool hybrid fuel cell buses for AC Transit and others, including CTTRANSIT. This process will be discussed further in the What's Next for CTTRANSIT section.

\section{Bus Use and Availability}

Bus use and availability are indicators of reliability. Lower bus usage could indicate downtime for maintenance or an intentional reduction of planned work for the buses. This section provides a summary of bus usage and availability for the two groups studied.

Table 1 summarizes the average monthly mileage accumulation by the fuel cell bus and the diesel study group for the evaluation period. During this period, the fuel cell bus accumulated 24,127 miles, and the fuel cell systems accumulated 3,544 hours. These numbers indicate an overall average speed of $6.8 \mathrm{mph}$, which is significantly slower than the average CTTRANSIT speed of $12 \mathrm{mph}$ and the $10-\mathrm{mph}$ Star route average.

The diesel buses operated a monthly average of 3,265 miles each as compared to the fuel cell bus, which had a monthly average of 1,723 miles. This indicates that the fuel cell buses traveled only $53 \%$ of the miles that the diesel buses did during the same period. However, the monthly average miles for the fuel cell bus are more than double what was reported previously in the preliminary evaluation results (808 miles/month). The attempt to increase significantly the usage of the fuel cell bus has clearly been successful.

The fuel cell bus accumulated 18,901 miles and 2,823 hours on the fuel cell power system installed on January 15, 2008, and changed out on November 24, 2008. UTC Power reported that the fuel cell power system did not have significant power degradation as had been experienced in the past (as early as 800 hours of operation). As mentioned above, this power system was removed in preference to testing a new fuel cell power system for the new order of hybrid fuel cell buses for AC Transit (and ultimately 2-4 buses for CTTRANSIT operation).

Table 1. Average Monthly Mileage (Evaluation Period)

\begin{tabular}{|c|c|c|c|c|c|c|}
\hline Bus & $\begin{array}{c}\text { Starting } \\
\text { Hubodometer }\end{array}$ & $\begin{array}{c}\text { Ending } \\
\text { Hubodometer }\end{array}$ & $\begin{array}{c}\text { Total } \\
\text { Mileage }\end{array}$ & Months & $\begin{array}{c}\text { Monthly } \\
\text { Average Mileage }\end{array}$ & $\begin{array}{c}\text { Fuel Cell } \\
\text { System Hours }\end{array}$ \\
\hline FCB/701 & $\mathbf{5 , 0 8 8}$ & $\mathbf{2 9 , 2 1 5}$ & $\mathbf{2 4 , 1 2 7}$ & $\mathbf{1 4}$ & $\mathbf{1 , 7 2 3}$ & $\mathbf{3 , 5 4 4}$ \\
\hline 725 & 15,861 & 59,931 & 40,070 & 14 & 2,862 & N/A \\
\hline 726 & 15,391 & 60,103 & 44,712 & 14 & 3,194 & N/A \\
\hline 727 & 15,143 & 63,488 & 48,345 & 14 & 3,453 & N/A \\
\hline Diesel & & & $\mathbf{1 3 7 , 1 2 7}$ & $\mathbf{4 2}$ & $\mathbf{3 , 2 6 5}$ & N/A \\
\hline
\end{tabular}

Another indicator of reliability is availability - the percent of days that a bus is actually available compared to the days the bus is planned for operation. Figure 9 shows monthly availability for the fuel cell bus during the evaluation period. Most of the availability issues were due to problems with the traction batteries and the hybrid propulsion and hydrogen fuel system. The figure shows that the fuel cell bus operated within $10 \%$ of the availability target nine out of the 14 months in this evaluation period including two months of $100 \%$ availability. Overall availability for the fuel cell bus during the evaluation period was $77 \%$. 


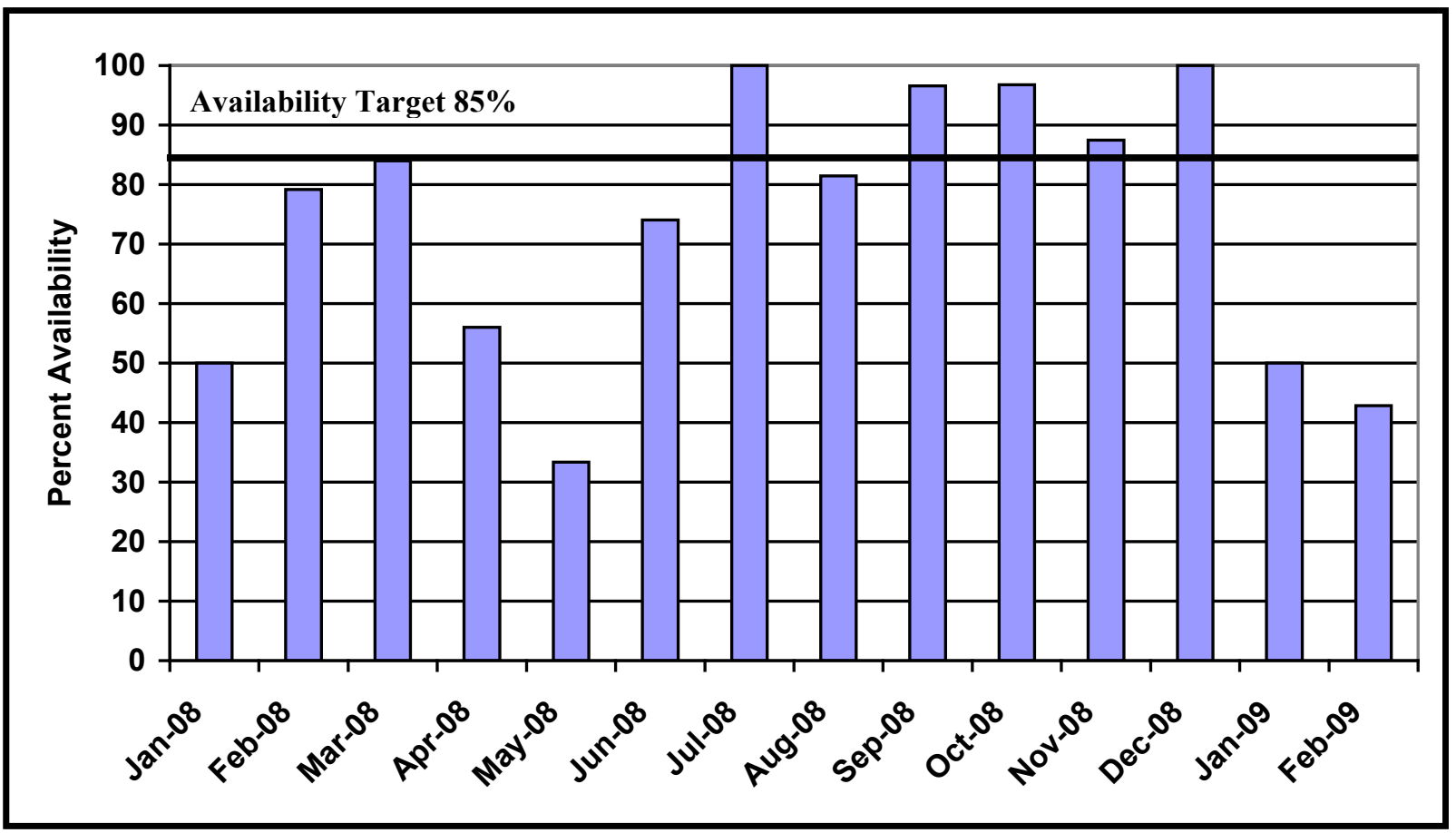

Figure 9. Availability for the fuel cell bus

Figure 10 shows the uses of the fuel cell bus when it was available for service during the evaluation period. This bus was used $93 \%$ of the time on route in service and $6 \%$ in support of event activities. Figure 11 shows the reasons that the bus was unavailable for service. The primary reasons for unavailability are for the ISE hybrid propulsion system at $39 \%$, problems with the ZEBRA/traction batteries at 30\%, and CTTRANSIT maintenance at $23 \%$. Issues with the UTC Power fuel cell system caused unavailability of the bus $8 \%$ of that time. This shows significant improvement from what was reported in the first evaluation report (The fuel cell system accounted for $53 \%$ of the unavailability).

Significant issues with the fuel cell bus included a problem with the hybrid propulsion system, ongoing issues with the traction batteries, and a problem with the hydrogen fuel storage system on the bus:

- Hybrid propulsion system - There was a problem with the hybrid propulsion system starting May 9, 2008, and this problem took until June 7, 2008, to resolve. At first, the problem was thought to be an inverter but was finally resolved by replacing a propulsion motor. The problem was difficult to resolve because it had to be done long distance (ISE Corp. is in San Diego, California) and because of confusion with ordering and shipping the correct parts.

- Traction batteries - The manufacturer of the ZEBRA batteries (MES-DEA) provided UTC Power and CTTRANSIT training and troubleshooting information. This new information has been extremely helpful in better understanding how to return the bus to service quickly once a problem with the traction batteries occurs. 
- On-board hydrogen storage - The fuel cell bus had a hydrogen leak in the fuel storage system that was difficult to identify and then difficult to resolve/repair. The bus was unavailable from January 16, 2009, through February 16, 2009. Ultimately, the problem was traced to a pressure-relief device on the high-pressure side of the main pressure regulator that feeds the fuel cell hydrogen manifold. Some of the delay in repairing the bus was due to the bus being out of warranty.

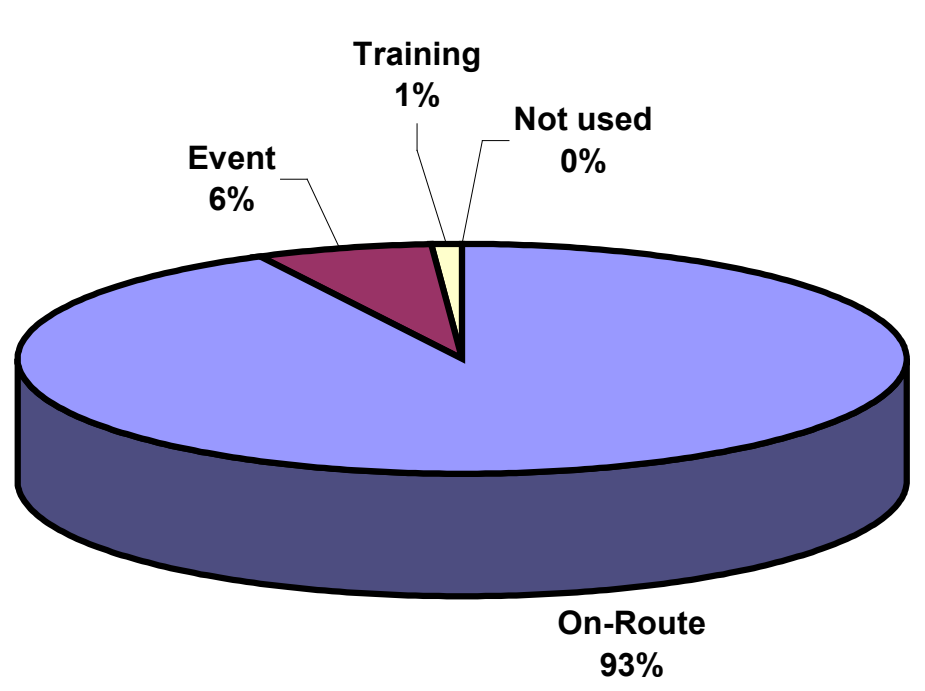

Figure 10. Use of the fuel cell bus when available for service

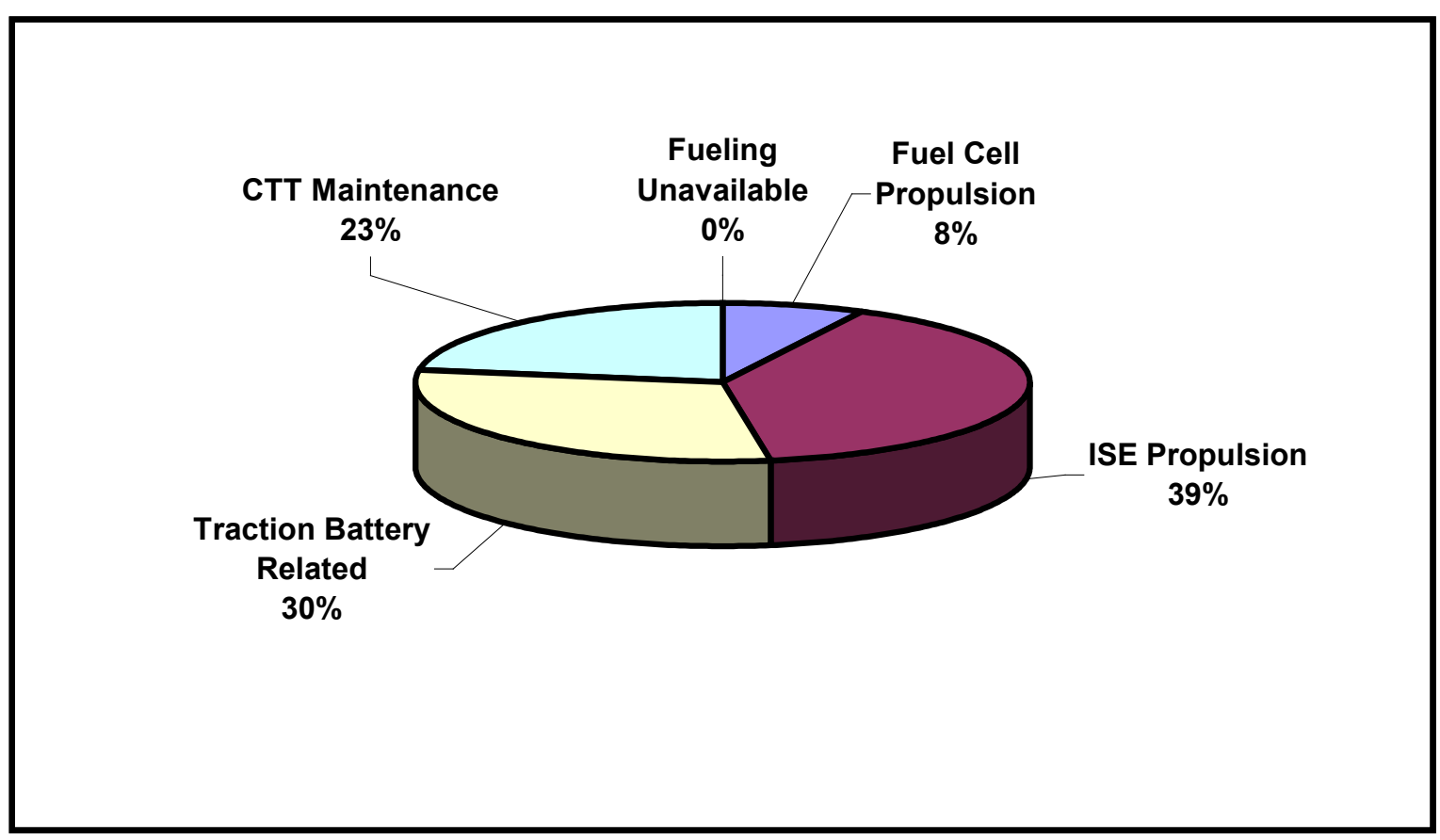

Figure 11. Categorization for fuel cell bus unavailability 


\section{Fuel Economy and Cost}

Hydrogen fuel is supplied by the UTC Power fueling station (discussed above). The hydrogen is dispensed at up to 5,000 psi for the fuel cell transit bus. During the evaluation period, UTC Power employees provided all fueling services, and fueling data were recorded by CTTRANSIT. Table 2 shows hydrogen and diesel fuel consumption and fuel economy for the study buses during the evaluation period. Overall, the fuel cell bus averaged 4.73 miles per $\mathrm{kg}$ of hydrogen, which equates to 5.34 miles per diesel gallon equivalent (DGE). The energy conversion from $\mathrm{kg}$ of hydrogen to DGE is provided at the end of Appendix F. As noted above, the buses are plugged in each night to recharge the batteries. The electric energy added to the fuel cell buses each night currently is not accounted for in the fuel economy calculation ${ }^{5}$.

Table 2. Fuel Use and Economy (Evaluation Period)

\begin{tabular}{|c|c|c|c|c|c|}
\hline Bus & $\begin{array}{c}\text { Mileage } \\
\text { (Fuel Base) }\end{array}$ & Hydrogen (kg) & $\begin{array}{c}\text { Miles per } \\
\mathbf{k g}\end{array}$ & $\begin{array}{c}\text { Diesel Equivalent } \\
\text { Amount (Gallon) }\end{array}$ & $\begin{array}{c}\text { Miles per } \\
\text { Gallon (mpg) }\end{array}$ \\
\hline FCB 701 Total & $\mathbf{2 4 , 1 2 7}$ & $\mathbf{5 , 1 0 2 . 9}$ & $\mathbf{4 . 7 3}$ & $\mathbf{4 , 5 1 6}$ & $\mathbf{5 . 3 4}$ \\
\hline 725 & 40,070 & & & 11,860 & 3.72 \\
\hline 726 & 44,251 & & & 12,349 & 3.58 \\
\hline 727 & 47,978 & & & 13,022 & 3.68 \\
\hline Diesel Total & $\mathbf{1 3 6 , 2 9 9}$ & & & $\mathbf{3 7 , 2 3 1}$ & $\mathbf{3 . 6 6}$ \\
\hline
\end{tabular}

For the evaluation period, the three diesel baseline buses averaged $3.66 \mathrm{mpg}$, which indicates the fuel economy for the fuel cell bus is an overall $46 \%$ higher than that of the diesel buses. Figure 12 shows the average monthly fuel economy in both miles per kg and miles per DGE for the fuel cell bus, and in miles per gallon for the diesel buses. For reference, the chart also shows the average monthly high and low temperatures. During the evaluation period, a clear jump (around $5 \%$ ) in the diesel bus fuel economy occurred. CTTRANSIT reports that this may be the result of training provided to operators focused on increasing fuel economy by the way the bus is driven.

\footnotetext{
${ }^{5}$ Additional study has been completed at AC Transit to estimate the amount of energy consumed in the recharging process and the impact to the fuel economy calculation. Results from that effort indicate that the charging energy accounts for up to $5 \%$ of the total energy consumed by the bus.
} 


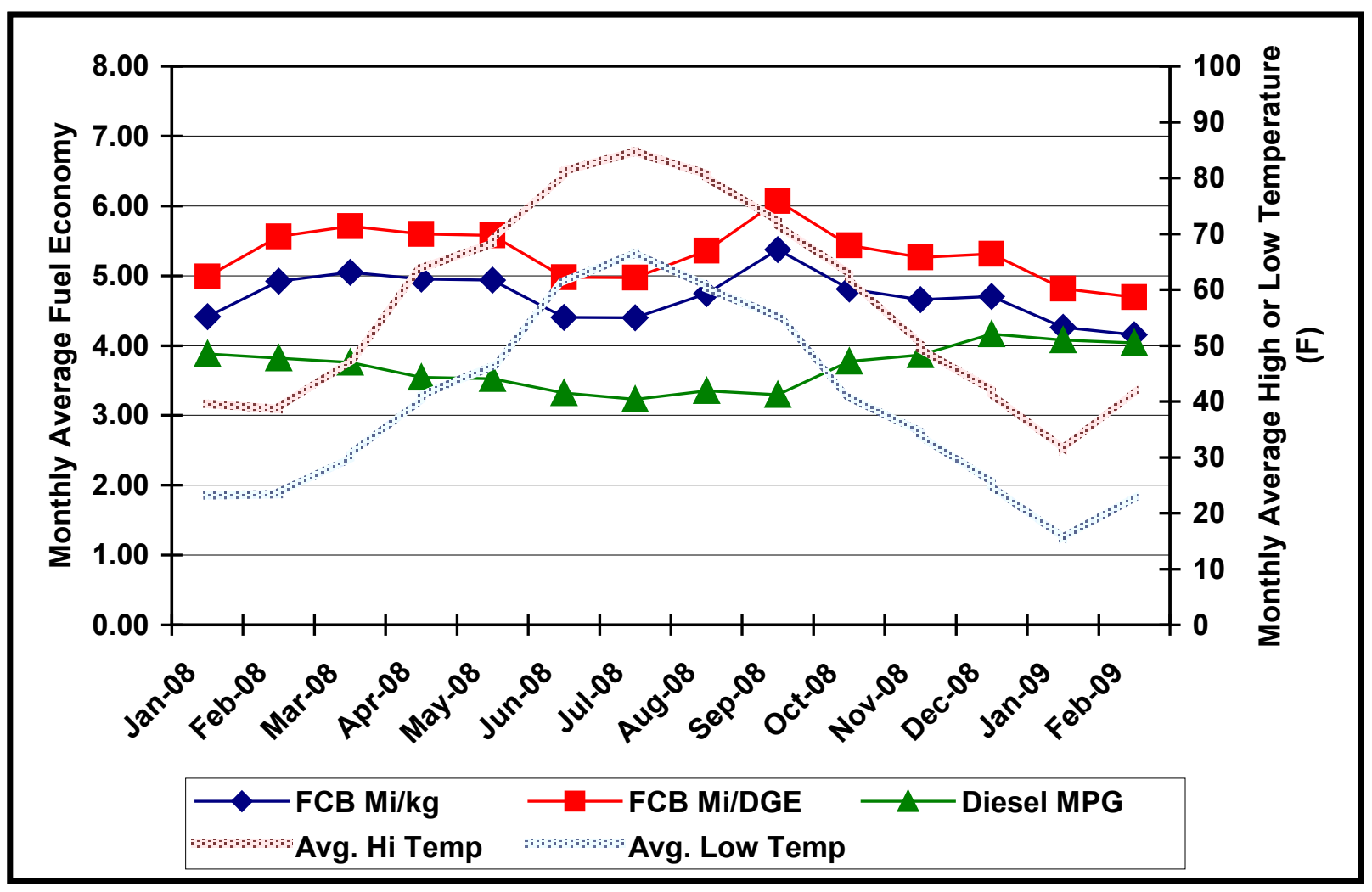

Figure 12. Average monthly fuel economy (evaluation period)

The operating cost for the UTC Power hydrogen production and dispensing is currently unknown; however, the current cost of fuel charged by UTC Power is $\$ 5.29 / \mathrm{kg}$. This amount does not include all the costs of purchasing, transporting, and dispensing the fuel. During the evaluation period, CTTRANSIT spent 343 hours of mechanic time driving the fuel cell bus to and from UTC Power for fueling. This cost is not included in the price of fuel, but it would add another $\$ 0.71$ per mile based on a $\$ 50$-per-hour labor rate. Using the $\$ 5.29$-per-kg cost for hydrogen fuel indicates that the cost per mile for the fuel cell bus is $\$ 1.12$, and adding the labor brings it to $\$ 1.83$ per mile. The average diesel fuel cost per gallon during the evaluation period is $\$ 2.70$. CTTRANSIT locked into this fixed cost for 12 months, which included the evaluation period. The diesel fuel cost per mile was $\$ 0.74$, or less than half the fuel cell bus fueling cost per mile.

\section{Maintenance Analysis}

The maintenance cost analysis presented here includes only the evaluation period (January 2008 through February 2009). Warranty costs are not included in the cost-per-mile calculations. All work orders for the study buses were collected and analyzed for this evaluation. For consistency, the maintenance labor rate was kept at a constant $\$ 50$ per hour; this does not reflect an average rate for CTTRANSIT. This section first covers total maintenance costs and then provides maintenance costs separated by bus system.

Total Maintenance Costs - Total maintenance costs include the price of parts and labor rates of $\$ 50$ per hour; this total does not include warranty costs. Cost per mile is calculated as follows. 
Cost per mile $=[($ labor hours $* \$ 50 / \mathrm{hr})+$ parts cost $] /$ mileage

Table 3 shows total maintenance costs for the fuel cell and diesel buses. Note that the fuel cell bus maintenance costs shown in the table are nearly 2.5 times higher because of the on-site warranty work done by the CTTRANSIT mechanics and because these were not charged back as warranty claims. The mechanic labor costs for taking the fuel cell bus to and from fueling at UTC Power also are not included here.

Table 3. Total Maintenance Costs (Evaluation Period)

\begin{tabular}{|c|c|c|c|c|}
\hline Bus & Mileage & Parts (\$) & Labor Hours & Cost per Mile (\$) \\
\hline Total Fuel Cell 701 & $\mathbf{2 4 , 1 2 7}$ & $\mathbf{2 , 7 2 3 . 6 4}$ & $\mathbf{4 4 8 . 1}$ & $\mathbf{1 . 0 4}$ \\
\hline 725 & 44,070 & $8,981.76$ & 324.5 & 0.57 \\
\hline 726 & 44,712 & $4,022.51$ & 241.3 & 0.36 \\
\hline 727 & 48,345 & $4,132.37$ & 232.4 & 0.33 \\
\hline Total Diesel & $\mathbf{1 3 7 , 1 2 7}$ & $\mathbf{1 7 , 1 3 6 . 6 4}$ & $\mathbf{7 9 8 . 2}$ & $\mathbf{0 . 4 2}$ \\
\hline
\end{tabular}

As discussed previously, maintenance issues for the fuel cell bus centered on problems with the traction batteries, problems with a propulsion motor, a hydrogen fuel leak in the on-board fuel storage system, and the replacement of the fuel cell system. Most of the repair costs were to support troubleshooting and repairs for the heating, traction battery changeouts and replacement of battery management hardware, and support to UTC Power for changing the fuel cell power system.

Maintenance issues for the diesel buses included specific issues with an alternator (bus 725), a transmission problem (bus 725), and a problem with the engine charge air cooler (bus 726). In addition, all three buses had the turbochargers replaced under warranty during the evaluation period. Another significant maintenance cost was having four-wheel brake relines for two of the buses during the evaluation period.

The total maintenance costs - excluding warranty costs - are much less for the diesel buses. The per-bus results for the fuel cell buses compared with the diesel buses are as follows.

- Usage/Mileage: The fuel cell buses mileage is $47 \%$ lower than that of the diesel buses.

- Parts Costs: The parts for the fuel cell are 52\% less than those for the diesel buses.

- Labor Hours: The labor hours for the fuel cell buses are $68 \%$ higher than for the diesel buses.

- Cost per Mile (excluding warranty costs): The costs for the fuel cell buses are 2.5 times greater than those for diesel buses.

Maintenance Costs Broken Down by System - Table 4 shows maintenance costs by vehicle system and bus study group (excluding warranty costs). The vehicle systems shown in the table include the following.

- Cab, Body, and Accessories: Includes body, glass, and paint repairs following accidents; $\mathrm{cab}$ and sheet metal repairs on seats and doors; and accessory repairs, such as hubodometers and radios. 
- Propulsion-Related Systems: Includes repairs for exhaust, fuel, engine, electric motors, fuel cell modules, propulsion control, non-lighting electrical (charging, cranking, ignition), air intake, cooling, and transmission.

- Preventive Maintenance Inspections (PMI): Includes labor for inspections during preventive maintenance.

- Brakes

- Frame, Steering, and Suspension

- Heating, Ventilation, and Air Conditioning (HVAC)

- Lighting

- Air System, General

- Axles, Wheels, and Drive Shaft

- Tires

The systems with the greatest percentage of maintenance costs for the fuel cell bus were propulsion related; frame, steering, and suspension; and cab, body, and accessories. Two of these systems also had the greatest maintenance costs for the diesel buses.

Table 4. Breakdown of Vehicle System Maintenance Cost per Mile (Evaluation Period)

\begin{tabular}{|l|c|c|c|c|}
\hline \multirow{2}{*}{\multicolumn{1}{|c|}{ System }} & \multicolumn{2}{c|}{ Fuel Cell } & \multicolumn{2}{c|}{ Diesel } \\
\cline { 2 - 5 } & $\begin{array}{c}\text { Cost per } \\
\text { Mile (\$) }\end{array}$ & $\begin{array}{c}\text { Percent of } \\
\text { Total (\%) }\end{array}$ & $\begin{array}{c}\text { Cost per } \\
\text { Mile (\$) }\end{array}$ & $\begin{array}{c}\text { Percent of } \\
\text { Total (\%) }\end{array}$ \\
\hline Cab, Body, and Accessories & 0.05 & 5 & 0.13 & 31 \\
\hline Propulsion Related & 0.76 & 73 & 0.12 & 29 \\
\hline PMI & 0.05 & 5 & 0.07 & 17 \\
\hline Brakes & 0.02 & 2 & 0.05 & 12 \\
\hline Frame, Steering, and Suspension & 0.08 & 7 & 0.01 & 2 \\
\hline HVAC & 0.05 & 5 & 0.02 & 5 \\
\hline Lighting & 0.02 & 2 & 0.00 & 0 \\
\hline Air, General & 0.00 & 0 & 0.01 & 2 \\
\hline Axles, Wheels, and Drive Shaft & 0.00 & 0 & 0.00 & 0 \\
\hline Tires & 0.01 & 1 & 0.01 & 2 \\
\hline Total & $\mathbf{1 . 0 4}$ & $\mathbf{1 0 0}$ & $\mathbf{0 . 4 2}$ & $\mathbf{1 0 0}$ \\
\hline
\end{tabular}

Propulsion-Related Maintenance Costs - Propulsion-related vehicle systems include the exhaust, fuel, engine, electric propulsion, air intake, cooling, non-lighting electrical, and transmission systems. Table 5 shows the propulsion-related system repairs by category for the two study groups during the evaluation period. The maintenance costs do not include the work done by the UTC Power personnel, which was covered under warranty. 
Table 5. Propulsion-Related Maintenance Costs by System (Evaluation Period) ${ }^{6}$

\begin{tabular}{|c|c|c|}
\hline Maintenance System Costs & Fuel Cell & Diesel \\
\hline Mileage & 24,127 & 137,127 \\
\hline \multicolumn{3}{|c|}{ Total Propulsion-Related Systems (Roll-Up) } \\
\hline Parts cost $(\$)$ & $1,490.82$ & $6,666.62$ \\
\hline Labor hours & 335.2 & 195.6 \\
\hline Total cost $(\$)$ & $18,248.82$ & $16,445.62$ \\
\hline Total cost (\$) per mile & 0.76 & 0.12 \\
\hline \multicolumn{3}{|l|}{ Exhaust System Repairs } \\
\hline Parts cost $(\$)$ & 0.00 & 0.00 \\
\hline Labor hours & 0.0 & 6.5 \\
\hline Total cost $(\$)$ & 0.00 & 325.00 \\
\hline Total cost (\$) per mile & 0.00 & 0.00 \\
\hline \multicolumn{3}{|l|}{ Fuel System Repairs } \\
\hline Parts cost $(\$)$ & 277.30 & 658.82 \\
\hline Labor hours & 8.3 & 3.8 \\
\hline Total cost (\$) & 693.80 & 846.32 \\
\hline Total cost (\$) per mile & 0.03 & 0.01 \\
\hline \multicolumn{3}{|l|}{ Powerplant System Repairs } \\
\hline Parts cost $(\$)$ & 0.00 & 945.52 \\
\hline Labor hours & 103.4 & 29.3 \\
\hline Total cost (\$) & $5,171.00$ & $2,412.02$ \\
\hline Total cost (\$) per mile & 0.21 & 0.02 \\
\hline \multicolumn{3}{|c|}{ Electric Motor and Propulsion Repairs } \\
\hline Parts cost $(\$)$ & 33.45 & 0.00 \\
\hline Labor hours & 216.9 & 0.0 \\
\hline Total cost $(\$)$ & $10,878.95$ & 0.00 \\
\hline Total cost (\$) per mile & 0.45 & 0.00 \\
\hline \multicolumn{3}{|c|}{$\begin{array}{l}\text { Non-Lighting Electrical System Repairs (General Electrical, Charging, } \\
\text { Cranking, Ignition) }\end{array}$} \\
\hline Parts cost $(\$)$ & 467.48 & $3,308.31$ \\
\hline Labor hours & 6.5 & 18.4 \\
\hline Total cost $(\$)$ & 792.48 & $4,229.31$ \\
\hline Total cost (\$) per mile & 0.03 & 0.03 \\
\hline \multicolumn{3}{|l|}{ Air Intake System Repairs } \\
\hline Parts cost $(\$)$ & 622.69 & $1,318.89$ \\
\hline Labor hours & 0.00 & 16.5 \\
\hline Total cost $(\$)$ & 622.69 & $2,143.89$ \\
\hline Total cost (\$) per mile & 0.03 & 0.02 \\
\hline \multicolumn{3}{|l|}{ Cooling System Repairs } \\
\hline Parts cost $(\$)$ & 89.90 & 337.66 \\
\hline Labor hours & 0.0 & 51.5 \\
\hline Total cost $(\$)$ & 89.90 & $2,912.66$ \\
\hline Total cost (\$) per mile & 0.00 & 0.02 \\
\hline \multicolumn{3}{|l|}{ Transmission Repairs } \\
\hline Parts cost $(\$)$ & 0.00 & 97.42 \\
\hline Labor hours & 0.0 & 69.6 \\
\hline Total cost (\$) & 0.00 & $3,576.42$ \\
\hline Total cost (\$) per mile & 0.00 & 0.03 \\
\hline
\end{tabular}

\footnotetext{
${ }^{6}$ Warranty costs are not included
} 


\section{Roadcall Analysis}

A roadcall ( $\mathrm{RC}$ ) or revenue vehicle system failure (as named in the National Transit Database) is defined as a failure of an in-service bus that causes the bus to be replaced while it is on route, or one that causes a significant delay in schedule. If the problem with the bus can be repaired during a layover and the schedule is maintained, then this is not considered a RC. The analysis provided here includes only RCs that were caused by "chargeable" failures. Chargeable RCs include systems that can physically disable the bus from operating while it is on route, such as interlocks (doors, air system), engine, etc., or things that are deemed safety issues if operation of the bus continued. Chargeable RCs do not include roadcalls for things such as problems with radios or destination signs.

Table 6 shows the RCs and miles between the roadcalls (MBRC) for each study bus categorized by all RCs and propulsion-related-only RCs. The diesel buses have much better MBRC rates for both categories. This fact is indicative of the low usage and prototype status of the fuel cell bus. Issues that caused propulsion-related RCs for the fuel cell bus are as follows:

- $\quad$ Traction batteries -12

- Hybrid propulsion -2

- Fuel cell power system - 4

- Hydrogen fuel system (on-board) - 1

Table 6. Roadcalls and Miles Between Roadcalls (Evaluation Period)

\begin{tabular}{|c|c|c|c|c|c|c|}
\hline Bus & Mileage & $\begin{array}{c}\text { All } \\
\text { Roadcalls }\end{array}$ & All MBRC & $\begin{array}{c}\text { Propulsion } \\
\text { Roadcalls }\end{array}$ & $\begin{array}{c}\text { Propulsion } \\
\text { MBRC }\end{array}$ & $\begin{array}{c}\text { Fuel Cell } \\
\text { only MBRC }\end{array}$ \\
\hline Total FCB & $\mathbf{2 4 , 1 2 7}$ & $\mathbf{2 1}$ & $\mathbf{1 , 1 4 9}$ & $\mathbf{1 9}$ & $\mathbf{1 , 2 7 0}$ & $\mathbf{6 , 0 3 2}$ \\
\hline 725 & 40,070 & 7 & 6,296 & 5 & 8,814 & - \\
\hline 726 & 44,712 & 7 & 6,387 & 7 & 6,387 & - \\
\hline 727 & 48,375 & 4 & 12,086 & 4 & 12,086 & - \\
\hline Total Diesel & $\mathbf{1 3 7 , 1 2 7}$ & $\mathbf{1 8}$ & $\mathbf{7 , 6 1 8}$ & $\mathbf{1 6}$ & $\mathbf{8 , 5 7 0}$ & - \\
\hline
\end{tabular}

\section{What's Next for CTTRANSIT}

CTTRANSIT started operation with their fuel cell bus in April 2007 and continues to operate the bus. As reported above, the fuel cell power system was last replaced on November 24, 2008, with UTC Power's newest version of their fuel cell power system. At that point in time, the fuel cell bus had not yet reached the full warranty period, with 400 hours of operation remaining on the fuel cell power system. CTTRANSIT and UTC Power agreed that the newer fuel cell power system would have a warranty period that included the remaining 400 hours so that the current system has a warranty period of 4,400 hours of operation. This additional warranty $(4,000 \mathrm{hrs})$ is being included in anticipation of a contract for continued operation of the bus under federal funding.

At this point in the demonstration of this single fuel cell bus, CTTRANSIT plans to reduce the operation from the maximum operation (seven days a week) back to the weekday service along 
with some Saturday service and no Sunday service. This change is being done to reduce operating costs and is expected to extend the life of this demonstration bus another two to two and a half years.

The change in approach to service of this fuel cell bus does not indicate a loss of interest in the project but a redirect toward the new fuel cell buses planned for CTTRANSIT in Hartford. The current plan is for CTTRANSIT to operate up to four new fuel cell buses from Van Hool and UTC Power as part of FTA's National Fuel Cell Bus Program through the Northeast Advanced Vehicle Consortium and UTC Power, along with a fifth bus being purchased by CTTRANSIT with federal funding. The first of the new buses for NFCBP through NAVC is expected to arrive between September and October 2009.

In order to prepare for the arrival of new buses and operation of up to six fuel cell buses, CTTRANSIT has been working with the state to design and construct a new storage building at their depot. The funding for this new storage building has been secured, and the design is essentially complete. The new construction is planned to be bid during the summer of 2009 with construction complete by July 2010 . This timeline means that the newer fuel cell buses will spend their first winter outside plugged into power from the main facility to keep the fuel cell systems warm.

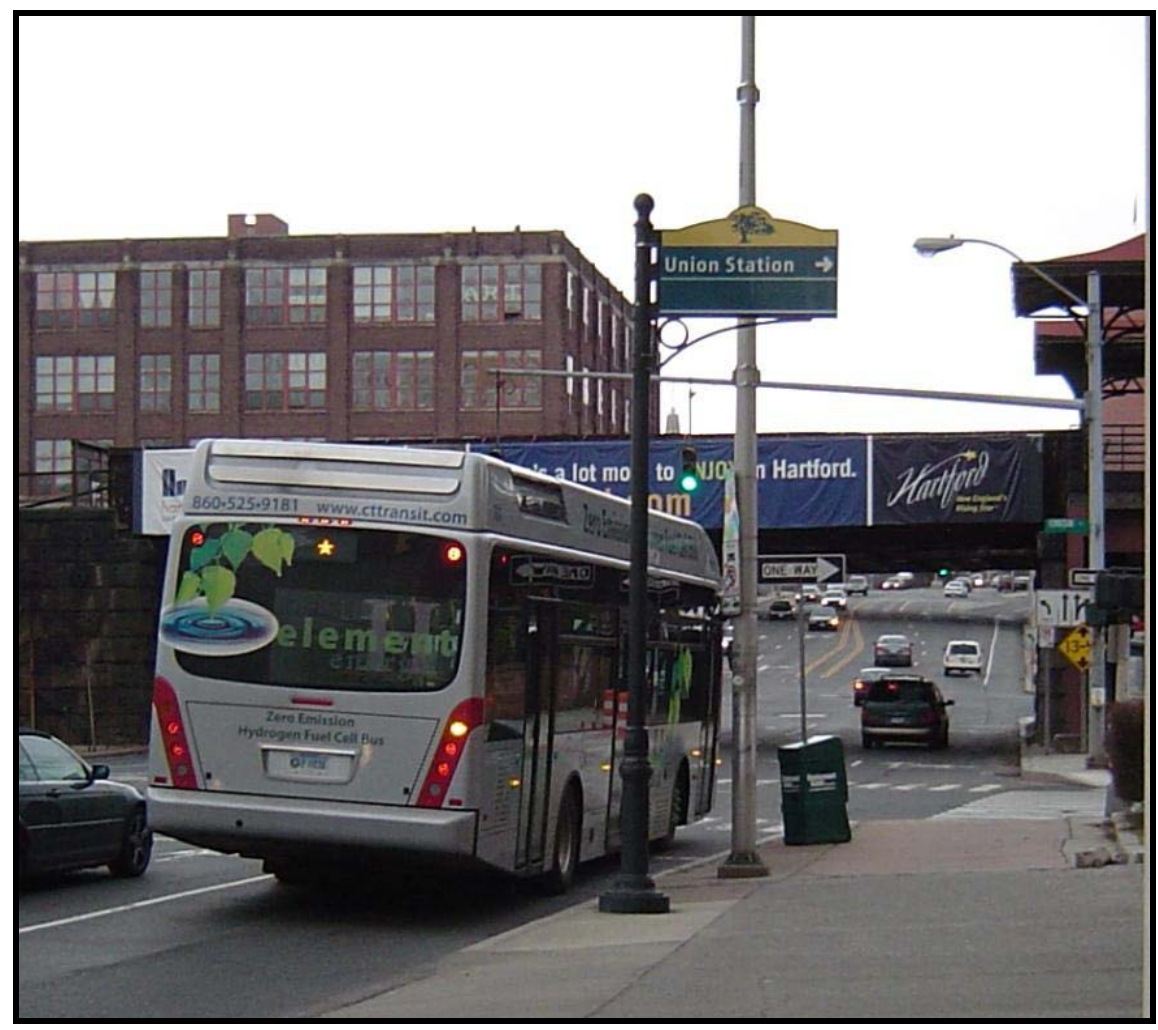




\section{Contacts}

U.S. Department of Energy

1000 Independence Ave., SW

Washington, DC 20585

John Garbak

Technology Validation Manager

Vehicle Technologies Program

Phone: 202-586-1723

E-mail: john.garbak@ee.doe.gov

\section{NREL}

1617 Cole Boulevard

Golden, CO 80401

Leslie Eudy

Senior Project Leader

Phone: 303-275-4412

E-mail: leslie eudy@nrel.gov

\section{Battelle}

505 King Avenue

Columbus, OH 43201

Kevin Chandler

Program Manager

Phone: 614-424-5127

E-mail: chandlek@,battelle.org

\section{CTTRANSIT}

100 Liebert Street

Hartford, CT 06141

Stephen Warren

Assistant General Manager,

Maintenance Services

Phone: (860) 522-8101 ext 223

E-mail: SWARREN@cttransit.com

\section{UTC Power}

195 Governor's Highway

South Windsor, CT 06074

Rakesh Radhakrishnan,

Program Manager, Transportation Programs

Phone: 860-727-2754

E-mail: rakeshr@utcpower.com

Jennifer Stewart

Fleet Aftermarket Support Engineer

Phone: 860-727-2509

E-mail: jennifer.stewart@utcpower.com

\section{ISE Corp}

12302 Kerran Street

Poway, CA 92064

Paul Scott

Chief Scientific Officer

Phone: 858-413-1742

E-mail:pscott@isecorp.com

MES-DEA S.A.

Via Laveggio, 15

$\mathrm{CH}-6855$ Stabio - Switzerland

Ing. Michael Metzger

Sales and Marketing Manager

Phone: +41 (0)91 6415311

E-mail: mmetzger@mes-dea.ch

Ing. Renato Manzoni

Customer Technical Support Manager

Phone: +41 (0)91 6415311

E-mail: rmanzoni@,mes-dea.ch 


\section{Related Reports}

All NREL Hydrogen and fuel cell-related evaluation reports can be downloaded from the following Web site: www.nrel.gov/hydrogen/proj_fc_bus_eval.html.

\section{Connecticut Transit}

Chandler, K.; Eudy, L. Connecticut Transit (CTTRANSIT) Fuel Cell Transit Bus: Preliminary Evaluation Results. NREL/TP-560-43847. Golden, CO: National Renewable Energy Laboratory, 2008.

NREL. CTTRANSIT Operates New England's First Fuel Cell Hybrid Bus. DOE/GO12008-2529. Golden, CO: National Renewable Energy Laboratory, 2008.

\section{General}

Eudy, L.; Chandler, K.; Gikakis, C. Fuel Cell Buses in U.S. Transit Fleets: Current Status 2008. NREL/TP-560-44133. Golden, CO: National Renewable Energy Laboratory, 2008.

NREL. Hydrogen and Fuel Cell Transit Bus Evaluations, Joint Evaluation Plan for the U.S. Department of Energy and the Federal Transit Administration. NREL/MP-560-42781. Golden, CO: National Renewable Energy Laboratory, 2008.

Eudy, L.; Chandler, K.; Gikakis, C. Fuel Cell Buses in U.S. Transit Fleets: Summary of Experiences and Current Status. NREL/TP-560-41967. Golden, CO: National Renewable Energy Laboratory, 2007.

\section{AC Transit}

Chandler, K.; Eudy, L. National Fuel Cell Bus Program: Accelerated Testing Evaluation Report and Appendices. FTA-CO-26-7004-2009.1. Golden, CO: National Renewable Energy Laboratory, 2009.

Chandler, K.; Eudy, L. Alameda-Contra Costa Transit District (AC Transit), Fuel Cell Transit Buses: Third Evaluation Report and Appendices. NREL/TP-560-43545-1, NREL/TP-560-435452. Golden, CO: National Renewable Energy Laboratory, 2008.

Chandler, K.; Eudy, L. Alameda-Contra Costa Transit District (AC Transit), Fuel Cell Transit Buses: Evaluation Results Update. NREL/TP-560-42249. Golden, CO: National Renewable Energy Laboratory, 2007.

Chandler, K.; Eudy, L. AC Transit, Fuel Cell Transit Buses: Preliminary Evaluation Results. NREL/TP-560-41041. Golden CO: National Renewable Energy Laboratory, 2007,

NREL. AC Transit Demos Three Prototype Fuel Cell Buses. DOE/GO-102006-2286. Golden, CO: National Renewable Energy Laboratory, 2006,

\section{SunLine}

Chandler, K.; Eudy, L. SunLine Transit Agency, Fuel Cell Transit Bus: Fourth Evaluation Report and Appendices, NREL/TP-560-44646-1, NREL/TP-560-44646-2. Golden, CO: National Renewable Energy Laboratory, 2009. 
Chandler, K.; Eudy, L. SunLine Transit Agency, Hydrogen-Powered Transit Buses: Third Evaluation Report and Appendices. NREL/TP-560-43741-1, NREL/TP-560-43741-2. Golden, CO: National Renewable Energy Laboratory, 2008.

NREL. SunLine Begins Extended Testing of Hybrid Fuel Cell Bus. DOE/GO12008-2610. Golden, CO: National Renewable Energy Laboratory, 2008.

Chandler, K.; Eudy, L. SunLine Transit Agency, Hydrogen-Powered Transit Buses: Evaluation Results Update. NREL/TP-560-42080. Golden, CO: National Renewable Energy Laboratory, 2007.

Chandler, K.; Eudy, L. SunLine Transit Agency, Hydrogen-Powered Transit Buses: Preliminary Evaluation Results. NREL/TP-560-41001. Golden, CO: National Renewable Energy Laboratory, 2007.

NREL. SunLine Tests HHICE Bus in Desert Climate. DOE/GO-102006-2333. Golden, CO: National Renewable Energy Laboratory, 2006.

NREL. SunLine Expands Horizons with Fuel Cell Bus Demo. DOE/GO-102006-2287. Golden, CO: National Renewable Energy Laboratory, 2006.

Chandler, K. Ten Years of Compressed Natural Gas (CNG) Operations at SunLine Transit Agency. NREL/SR-540-39180. Golden, CO: National Renewable Energy Laboratory, 2006.

Chandler, K.; Eudy, L. ThunderPower Bus Evaluation at SunLine Transit Agency. DOE/GO102003-1786. Golden, CO: National Renewable Energy Laboratory, 2003.

NREL. SunLine Test Drives Hydrogen Bus. DOE/GO-102003-1768. Golden, CO: National Renewable Energy Laboratory, 2003.

\section{Santa Clara Valley Transportation Authority}

Chandler, K.; Eudy, L. Santa Clara Valley Transportation Authority and San Mateo County Transit District, Fuel Cell Transit Buses: Evaluation Results. NREL/TP-560-40615. Golden, CO: National Renewable Energy Laboratory, 2006.

NREL. VTA, SamTrans Look into Future with Bus Demo. DOE/GO-102005-2147. Golden, CO: National Renewable Energy Laboratory, 2005. 


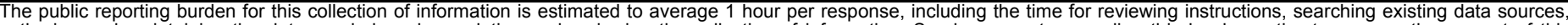

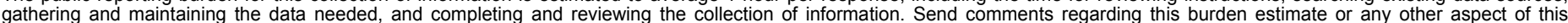

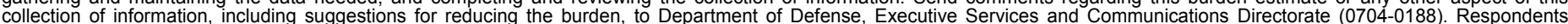

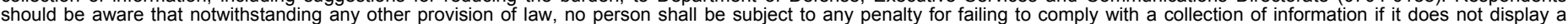

should be aware that notwithstand

PLEASE DO NOT RETURN YOUR FORM TO THE ABOVE ORGANIZATION.

\section{REPORT DATE (DD-MM-YYYY) \\ Revised September 2009 \\ 2. REPORT TYPE \\ Technical Report}

4. TITLE AND SUBTITLE

Connecticut Transit (CTTRANSIT) Fuel Cell Transit Bus: Second

Evaluation Report and Appendices
3. DATES COVERED (From - To)

May 2009

5a. CONTRACT NUMBER

DE-AC36-08-GO28308

5b. GRANT NUMBER

5c. PROGRAM ELEMENT NUMBER

5d. PROJECT NUMBER

NREL/TP-560-45670

5e. TASK NUMBER

FC087820

5f. WORK UNIT NUMBER
7. PERFORMING ORGANIZATION NAME(S) AND ADDRESS(ES)

National Renewable Energy Laboratory

1617 Cole Blvd.

Golden, CO 80401-3393

\section{PERFORMING ORGANIZATION REPORT NUMBER \\ NREL/TP-560-45670}

9. SPONSORING/MONITORING AGENCY NAME(S) AND ADDRESS(ES)

10. SPONSOR/MONITOR'S ACRONYM(S) NREL

11. SPONSORING/MONITORING AGENCY REPORT NUMBER

12. DISTRIBUTION AVAILABILITY STATEMENT

National Technical Information Service

U.S. Department of Commerce

5285 Port Royal Road

Springfield, VA 22161

13. SUPPLEMENTARY NOTES

14. ABSTRACT (Maximum 200 Words)

This report describes operations at Connecticut Transit (CTTRANSIT) in Hartford for one prototype fuel cell bus and three new diesel buses operating from the same location. The evaluation period in this report (January 2008 through February 2009) has been chosen to coincide with a UTC Power propulsion system changeout that occurred on January 15, 2008.

\section{SUBJECT TERMS}

fuel cell; fuel cell bus; fuel cell evaluation; fuel cell bus demonstration

\begin{tabular}{|c|c|c|}
\hline \multicolumn{3}{|c|}{ 16. SECURITY CLASSIFICATION OF: } \\
\hline $\begin{array}{l}\text { a. REPORT } \\
\text { Unclassified }\end{array}$ & $\begin{array}{l}\text { b. ABSTRACT } \\
\text { Unclassified }\end{array}$ & $\begin{array}{l}\text { c. THIS PAGE } \\
\text { Unclassified }\end{array}$ \\
\hline
\end{tabular}

\begin{tabular}{l|l|} 
17. & LIMITATION \\
OF ABSTRACT & $\begin{array}{l}\text { 18. } \\
\text { NUMBER } \\
\text { OF PAGES } \\
\text { UL }\end{array}$ \\
\end{tabular}

19a. NAME OF RESPONSIBLE PERSON

19b. TELEPHONE NUMBER (Include area code) 